\title{
Sharks, rays and skates (Chondrichthyes, Elasmobranchii) from the Upper Marine Molasse (middle Burdigalian, early Miocene) of the Simssee area (Bavaria, Germany), with comments on palaeogeographic and ecological patterns
}

\author{
Jaime A. Villafaña ${ }^{1,2}$ - Giuseppe Marramà $a^{1,9}$ - Stefanie $\mathrm{Klug}^{3}$ (1) - Jürgen Pollerspöck ${ }^{4} \cdot$ Markus Balsberger $^{5}$. \\ Marcelo Rivadeneira ${ }^{6,7,8} \oplus$. Jürgen Kriwet $^{1}(\mathbb{C}$
}

Received: 3 November 2019 / Accepted: 27 April 2020 / Published online: 2 June 2020

(c) The Author(s) 2020

\begin{abstract}
Elasmobranch remains are quite common in Miocene deposits and were the subject of numerous studies since the middle of the nineteenth century. Nevertheless, the taxonomic diversity of the Marine Molasse sharks, rays and skates is still largely unknown. Here, we describe 37 taxa from the lower Miocene of the Molasse Basin: 21 taxa could be identified at species level, whereas 15 taxa could only be assigned to genus and one taxon is left as order incertae sedis. The material was collected from deposits of the Auwiesholz Member of the Achen Formation (middle Burdigalian, middle Ottnangian age, ca. 17.8 Ma) exposed near Simssee, Upper Bavaria. This faunal assemblage is a mixture of shallow marine, near-coastal, pelagic and deep-water taxa. The fauna from Simssee displays different biogeographic dynamics at local and regional scales, possibly related to the intense climatic, oceanographic and tectonic events that occurred during the Eggenburgian-Ottnangian stages. The faunal relationships of the early Miocene chondrichthyan faunas from the Mediterranean Sea and Paratethys with others regions are established on the basis of qualitative (presence/absence) data. The beta diversity (Sørensen-Dice coefficient) of the Miocene Molasse elasmobranchs was used to characterize the taxonomic differentiation between localities and regions. According to our results, the fauna from Simssee shows close similarities with those from Switzerland, Austria, France and northern Germany. Faunal similarities and differences are mainly related to tectonic events and oceanographic variables (i.e. migration through seaway passages) or might represent collecting biases.
\end{abstract}

Keywords Chondrichthyes $\cdot$ Molasse $\cdot$ Burdigalian $\cdot$ Early Miocene $\cdot$ Paratethys $\cdot$ Beta diversity

Handling editor: Mike Reich.

Jaime A. Villafaña

villafanaj88@univie.ac.at

Giuseppe Marramà

giuseppe.marrama@unito.it

Stefanie Klug

stefanie.klug@gauss.uni-goettingen.de

Jürgen Pollerspöck

juergen.pollerspoeck@shark-references.com

Markus Balsberger

mbalsberger@gmx.de

Marcelo Rivadeneira

marcelo.rivadeneira@ceza.cl

Jürgen Kriwet

juergen.kriwet@univie.ac.at

1 Department of Palaeontology, University of Vienna,

Althanstraße 14, 1090 Vienna, Austria
2 Centro de Investigación en Recursos Naturales y Sustentabilidad, Universidad Bernardo O’Higgins, Santiago, Chile

3 School of Science (GAUSS), Georg-August University, 37077 Göttingen, Germany

4 Bavarian State Collection of Zoology, Munich, Germany

5 Achberg 11, 83259 Schleching, Germany

6 Centro de Estudios Avanzados en Zonas Áridas, Av. Ossandon 877, Coquimbo, Chile

7 Departamento de Biología Marina, Facultad de Ciencias del Mar, Universidad Católica del Norte, Coquimbo, Chile

8 Departamento de Biología, Universidad de La Serena, La Serena, Chile

9 Dipartimento di Scienze della Terra, Università degli Studi di Torino, Via Valperga Caluso, 35, 10125 Torino, Italy 


\section{Introduction}

After the Tethys Ocean had nearly completely vanished by the end of the Eocene, an isolated Paratethys Sea developed in the latest Eocene-earliest Oligocene related to the development of the Alpine mountains (Baldi 1980; Rusu 1988; Rögl 1999). This island chain acted as barrier partly separating the Paratethys from the Mediterranean Sea. The Paratethys extended from the Rhone Valley in the east towards Inner Asia. Marginal to the Paratethys, the Molasse Basin, which represents a foreland basin, developed in the Oligo-Miocene during the Alpine-Himalayan orogeny. The Molasse Basin of southern Germany was thus part of western Paratethys during the Miocene.

The Paratethys and Mediterranean seas experienced dramatic changes during their development (Rögl 1999; Piller et al. 2007; Sant et al. 2017). During the Eggenburgian (lower Burdigalian), a broad sea passage between the Paratethys Sea and the IndoPacific Ocean was open, providing optimal environmental conditions for marine faunas and opportunities for widespread faunal exchanges (Rögl 1999). Additionally, a seaway passage through the Alpine fore-deep between the Mediterranean and Paratethys was open. Later, during the Ottnangian (middle Burdigalian), the sea passage into the Indo-Pacific Ocean was closed due the collision of Africa and Arabia with the Anatolian plate. The connection between the Western-Central Paratethys and the Mediterranean seas still persisted through the Rhine Graben, but the eastern Paratethys was already isolated (i.e. it informed the socalled Kotsakhurian Sea). All these events also induced changes in sea levels, salinity and temperature (Haq et al. 1988). Studies based on early Miocene marine invertebrates of Europe indicate that these intense climatic and oceanographic events had important effects on diversification patterns of organisms (Kroh 2007).

Remains of sharks, rays and skates generally are quite common in Miocene sediments of the Paratethys (Barthelt et al. 1991; Kocsis 2007; Reinecke et al. 2011; Schultz 2013; Pollerspöck and Straube 2017; Szabó and Kocsis 2016; Underwood and Schlögl 2013), but despite all progress accomplished in the last decades, our understanding of Miocene elasmobranchs taxonomic diversities and faunal relationships remains very incomplete. Here, we document an elasmobranch assemblage from the lower Miocene Upper Marine Molasse of the western Paratethys and present results about their relationships with other faunas from the early Miocene.

\section{Materials and methods}

\section{Data collection}

A total of 466 elasmobranch specimens (including teeth and tail spines) were recovered by screen washing and surface collecting from several points along the Auwiesholz
Member of the Achen Formation in the Simssee area (Bavaria, S. Germany, Fig. 1), during several trips conducted by two of the authors (JP and MB) and other collaborators in the late 90s. Part of the material was collected by N. Rückert-Ülkümen (Bavarian State Collection of Palaeontology and Geology) near the village of Hirnsberg in 1993. The precise stratigraphic origin of all material, however, remains ambiguous. The Achen Formation is of middle Ottnangian age (middle Burdigalian, early Miocene, ca. 17.8 Ma) and denotes the second cycle of the Upper Marine Molasse in Bavaria (Pippèrr et al. 2007). The depositional setting represents an inner neritic environment basally, which deepens upwards. This interpretation was based on the presence of foraminifera (e.g. Ammonia) and ostracoda (e.g. Cytheretta), and vertebrates as bony fishes (e.g. Rhynchoconger) were also reported from this member. The elasmobranch fossil fauna described herein is almost coeval to the assemblage from the Baltringer Horizon in Baden-Württemberg, SW Germany (Probst 1879).

The fossils are housed in the Bayerische Staatssammlung für Paläontologie und Geologie at Munich, Germany, with the catalogue numbers bearing the prefix SNSB-BSPG 2019 III.

\section{Completeness of the taxonomic inventory}

We estimated the completeness of Simssee taxonomic inventory based on two complementary methods, assuming teeth/ spines represent different individuals. First, rarefaction was used to estimate the impact of sampling effort (specimens) on total taxonomic richness, where a plateau in the curve suggests a saturation trend (Sanders and Hessler 1969; Gotelli and Colwell 2011). Second, we estimated the true (i.e. discoverable) taxonomic richness based on the Chao

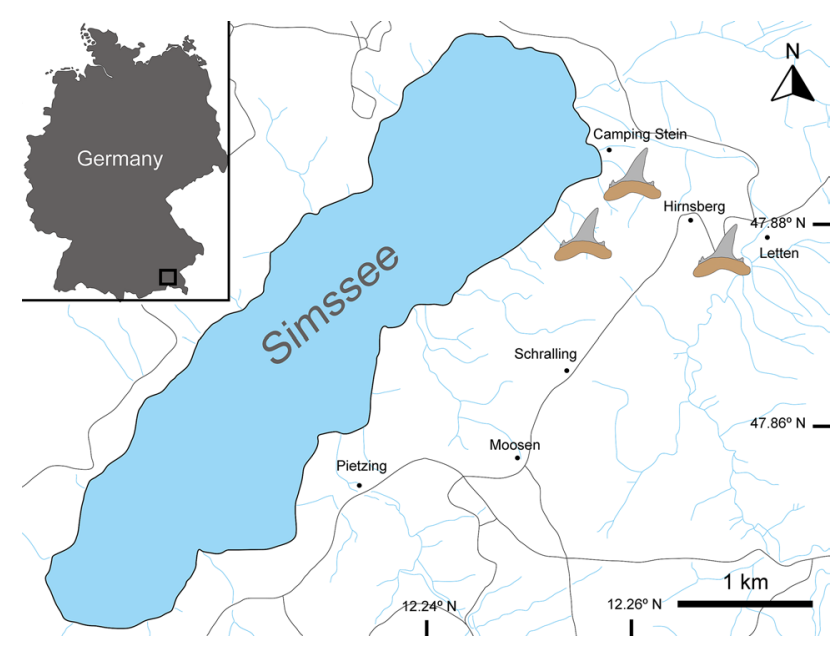

Fig. 1 Map of the Simssee area 
1 extrapolation index (Chao and Lee 1992; Colwell and Coddington 1994). The Chao 1 index is a non-parametric method that estimates the taxonomic richness in a given locality based on the number of rare taxa (i.e. with one and two individuals), providing a point estimator and an upper level confidence interval (95\%). The completeness of the taxonomic inventory was calculated as the fraction between the observed richness and the extrapolated richness (point estimator and upper level confidence interval). This method has been previously used in paleontological studies to estimate the discoverable species richness (e.g. Rivadeneira and Nielsen 2017).

\section{Faunal comparison}

We compared the faunal composition of Simssee with other early Miocene elasmobranch faunas worldwide by using a comprehensive literature dataset (see references in Table 2). Analyses were carried out at the genus level and pooling nearby localities to reduce identification and sampling biases. Since some localities lack precise age estimations, we only used localities that could be assigned to the Eggenburgian-Ottnangian time span (i.e. lower to middle Burdigalian). We used presence-absence data to estimate differences in generic composition between Simssee and other localities using the Sørensen-Dice similarity index. This index has been widely recommended in the ecological and paleontological literature due to its statistical properties (Hubalek 1982; Murguía and Villaseñor 2003; Hammer and Harper 2006; Jost et al. 2011). However, the Sørensen-Dice index, as any presence-absence similarity index, is sensitive to the completeness of taxonomic inventories (Jost et al. 2011).

\section{Systematic palaeontology}

Class Chondrichthyes Huxley, 1880

Subclass Elasmobranchii Bonaparte, 1838

Infraclass Neoselachii Compagno, 1977

Order Hexanchiformes Buen, 1926.

Family Chlamydoselachidae Garman, 1884

\section{Genus Chlamydoselachus Garman, 1884}

Type species. Chlamydoselachus anguineus Garman, 1884

\section{Chlamydoselachus sp.}

Figure 2a, b

Material. One antero-lateral tooth-SNSB-BSPG 2019 III-1.
Description. The antero-lateral tooth displays a one preserved long and slender cusp, which is lingually bent (Fig. 2a, b). The crown surface is mostly smooth, but faint vertical folds are present at the base of both cusp faces. In profile view, the lingual face is concave, whereas the labial face is convex. Although the root is incomplete and abraded, the small nutritive foramen is still distinguishable.

Remarks. The frilled shark Chlamydoselachus is currently represented by two species: $C$. africana which occurs in the Southeastern Atlantic, and $C$. anguineus, reported from the western Indian, Eastern Atlantic and Pacific Ocean (Uyeno et al. 1983; Ebert and Compagno 2009). The fossil record of Chlamydoselachus extends back to the Upper Cretaceous (Kriwet et al. 2016; Cappetta 2012). Early Miocene records of Chlamydoselachus were reported from Austria (Pfeil 1983; Schultz 2013), Germany (Barthelt et al. 1991), and the USA (Phillips et al. 1976).

As the single tooth is abraded and incompletely preserved, it is not possible to identify the specimen at specific level.

Family Hexanchidae Gray, 1851

Genus Notorynchus Ayres, 1855

Type species. Notorynchus maculatus Ayres, 1855

Notorynchus primigenius (Agassiz, 1843)

Figure 2c-1

Material. Two upper anterior teeth-SNSB-BSPG 2019 III2, SNSB-BSPG 2019 III-3; 2 upper antero-lateral teethSNSB-BSPG 2019 III-4, SNSB-BSPG 2019 III-5; 12 lower antero-lateral teeth-SNSB-BSPG 2019 III-6, SNSB-BSPG 2019 III-7 (4 teeth), SNSB-BSPG 2019 III-8 (7 teeth); 1 commissural tooth-SNSB-BSPG 2019 III-9 and 1 lower symphyseal tooth-SNSB-BSPG 2019 III-10.

Description. The upper anterior teeth have a slender and triangular cusp that is distally oriented (Fig. 2c, d). The cutting edges are smooth and do not reach the base of the crown. The root is high and rounded with a convex outline in labial and lingual views.

The upper antero-lateral teeth are labio-lingually compressed, but narrower than the lower teeth (Fig. 2e, f). The crown is composed of a main cusp followed by a secondary cusp that is distally oriented. The root is high and flat with almost straight basal aspect.

The lower antero-lateral teeth are labio-lingually compressed and mesio-distally elongated (Fig. $2 \mathrm{~g}$, h). The crown shows a comb-like shape with triangular cusps, which are distally oriented. The most complete specimen 


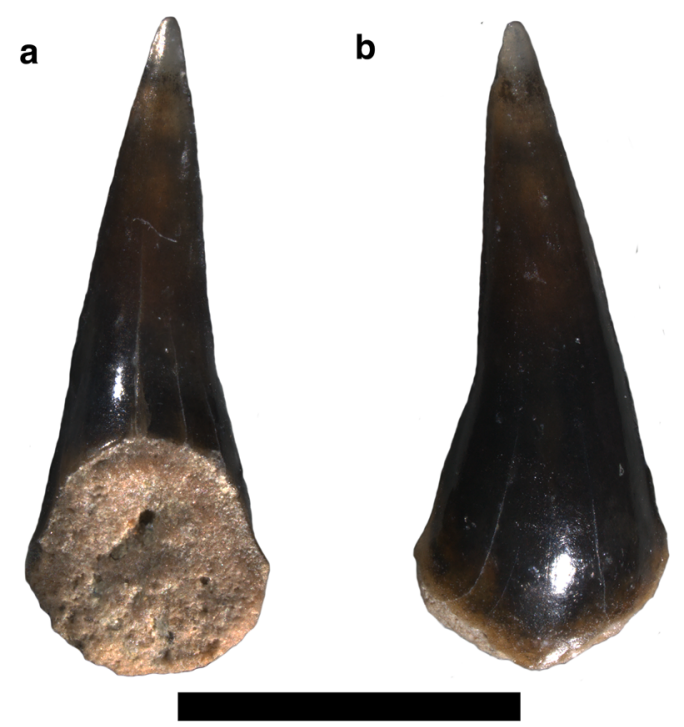

f
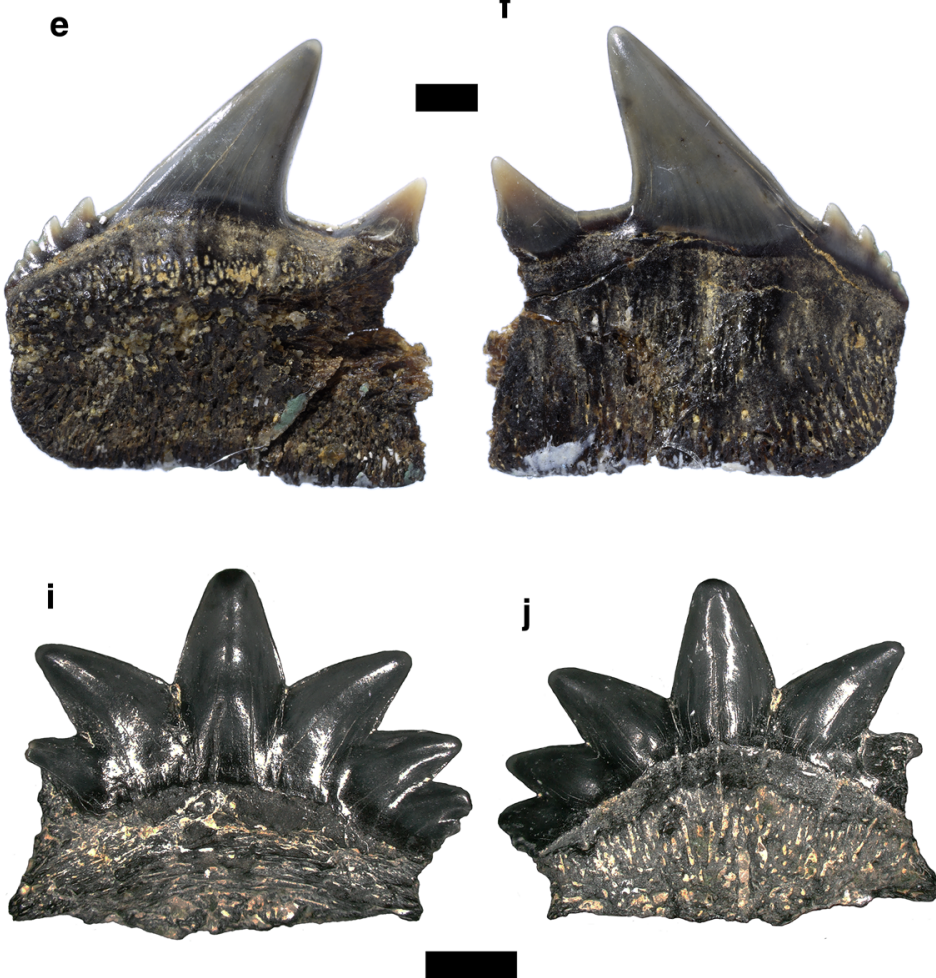
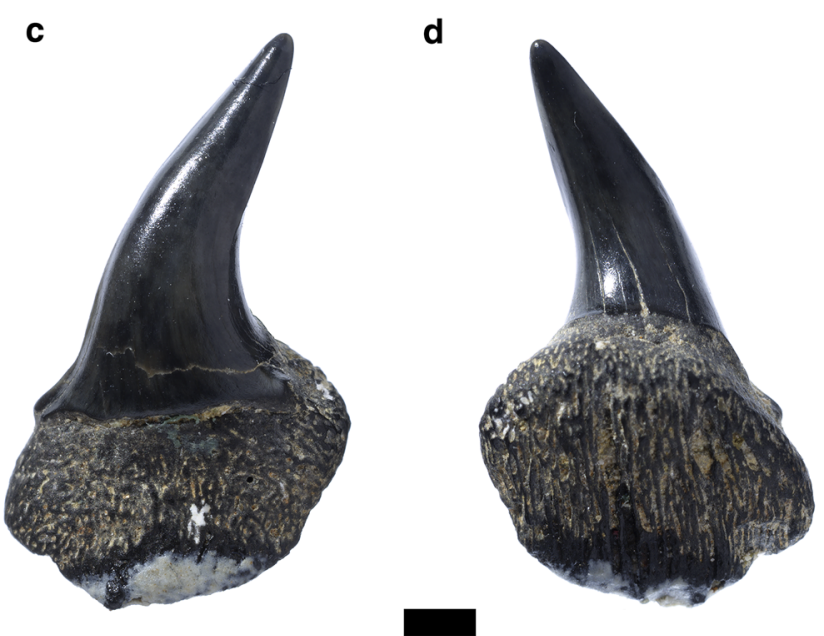

Fig. 2 Hexanchiformes. a, b Chlamydoselachus sp., antero-lateral tooth. c-l Notorynchus primigenius: $\mathbf{c}, \mathbf{d}$ anterior tooth, $\mathbf{e}, \mathbf{f}$ upper antero-lateral tooth, $\mathbf{g}, \mathbf{h}$ lower lateral tooth, $\mathbf{i}, \mathbf{j}$ lower symphyseal

bears six cusps decreasing in size distally. The mesial cutting edge is slightly convex with awl-shaped coarse serrations that become finer towards the base of the crown. The root is incomplete, being low and flat with rectilinear basal part.

The symphyseal tooth is mesio-distally compressed with a main straight cusp flanked by two mesial and three distal tooth, $\mathbf{k}, \mathbf{l}$ commissural tooth. Labial $\mathbf{a}, \mathbf{c}, \mathbf{e}, \mathbf{g}, \mathbf{i}, \mathbf{k}$; lingual $\mathbf{b}, \mathbf{d}, \mathbf{f}, \mathbf{h}$, j, l. Scale bar $2 \mathrm{~mm}$

secondary cusplets (Fig. 2i, j). The mesial secondary cusplets are mesially oriented, whereas the distal ones are distally oriented. The root is low and possibly abraded. The commissural tooth displays a very low crown, mesio-distally elongated (Fig. 2k, 1). The distal part of the crown is missing. The root is high and flat. 
Remarks The genus Notorynchus is nowadays only represented by the broadnose sevengill shark $N$. cepedianus, which is a cosmopolitan species occurring in warm temperate to subtropical seas, but which is absent in the North Atlantic and Mediterranean Sea (Compagno et al. 1989; Last and Stevens 2009). having teeth described here similar to $N$. primigenius from the early Miocene of Germany (Reinecke et al. 2011), we determine them as belonging to this species, whose fossil record ranges from the Oligocene to the Miocene (Cappetta 2012). Early Miocene records of $N$. primigenius were also reported from Austria (Schultz 2013), Germany (Probst 1879 as Notidanus primigenius; Lutzeier 1922; von Ihering 1927; Barthelt et al. 1991; Scholz and Bienert 1992; Baier et al. 2004; Höltke 2014; Sach 2016), France (Cappetta 1970, 1973, as Hexanchus primigenius), Hungary (Kordos and Solt 1984, as Hexanchus primigenius; Kocsis 2007), Slovakia (Holec et al. 1995), Switzerland (Leriche 1927; Fischli 1930, as Notidanus primigenius; Bolliger et al. 1995) and the USA (Kent 2018).

Order Squaliformes Goodrich, 1909

Family Squalidae Bonaparte, 1838

Genus Squalus Linnaeus, 1758

Type species. Squalus acanthias Linnaeus, 1758

\section{Squalus sp.}

Figure 3a, b

Material. Two lower antero-lateral teeth-SNSB-BSPG 2019 III-11, SNSB-BSPG 2019 III-12.

Description. These teeth show a broad, triangular and strongly distally bent cusp with a rounded apex (Fig. 3a, b). The distal heel is high with a convex outline. The distal and mesial cutting edges are completely smooth. In labial view, a long apron is present. In lingual view, the uvula is abraded but still distinguishable. The root is short.

Remarks. The genus Squalus is currently represented by 35 species worldwide distributed, including the Mediterranean Sea (Pollerspöck and Straube 2019). Squalus species inhabit the upper continental and insular slopes at tropical to temperate latitudes. The fossil record of Squalus extends back to the Upper Cretaceous. Early Miocene records were reported from Austria (Schultz 2013), Chile (Suarez et al. 2006; Villafaña et al. 2019), France (Ledoux 1972), Hungary (Kocsis 2007), Germany (Probst 1879; von Ihering 1927; Barthelt et al. 1991; Reinecke et al. 2008; Pollerspöck and Beaury 2014; Pollerspöck and Straube 2017), India (Mondal et al. 2009), Slovakia (Holec et al. 1995), Switzerland (Bolliger et al. 1995) and the USA (Emry and Eshelman 1998; Purdy et al. 2001; Kent 2018).
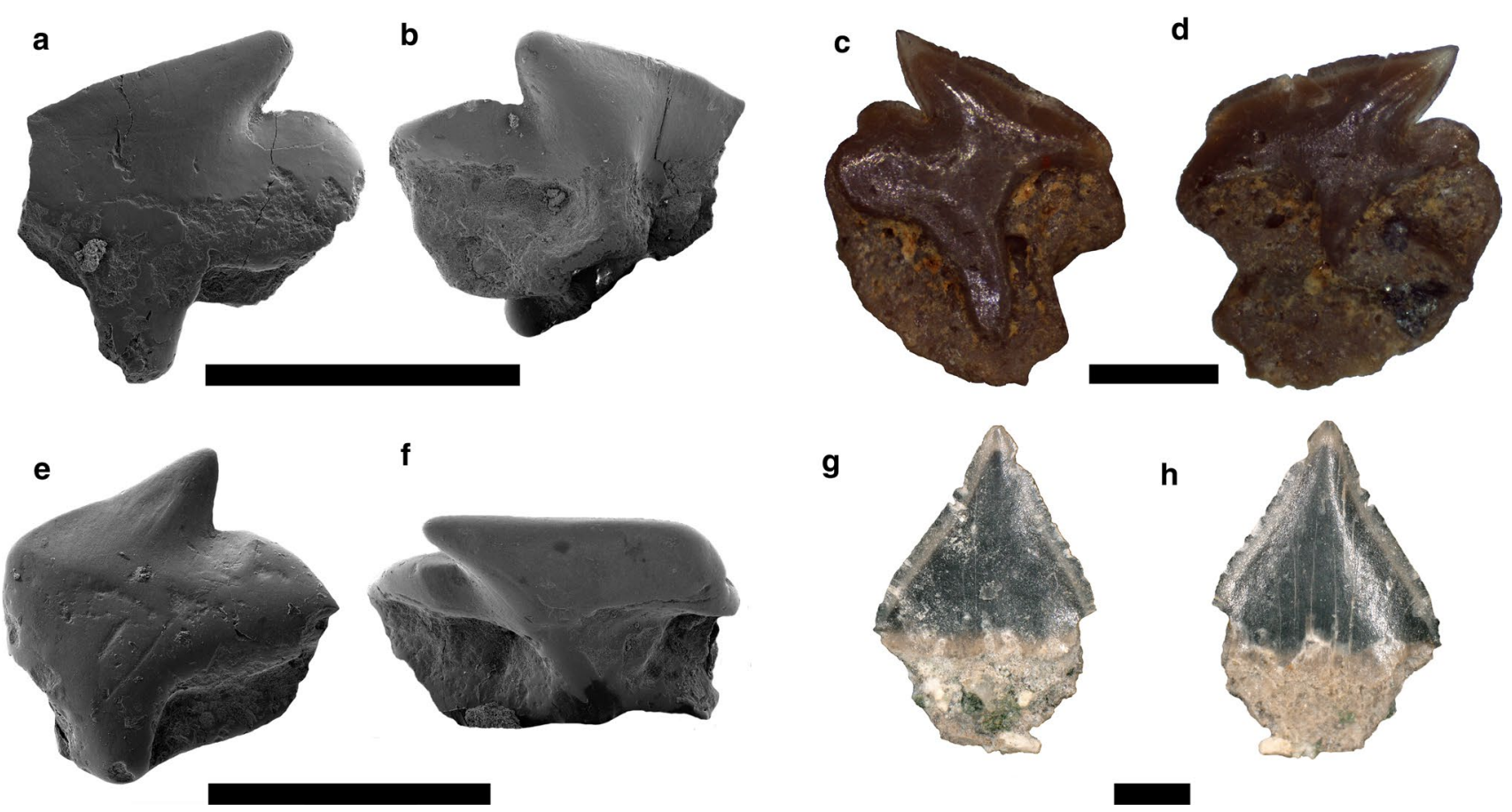

g

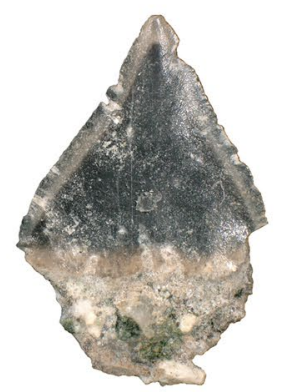

h

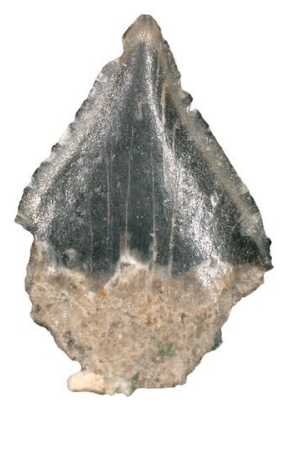

Fig. 3 Squaliformes. a, b Squalus sp., antero-lateral tooth, c, d Centrophorus granulosus, lower antero-lateral tooth, e, f Deania sp., lower antero-lateraol tooth, $\mathbf{g}, \mathbf{h}$ Isistius triangulus, lower anterior tooth. Labial $\mathbf{a}, \mathbf{c}, \mathbf{e}, \mathbf{g}$.; lingual $\mathbf{b}, \mathbf{d}, \mathbf{f}, \mathbf{h}$. Scale bar $1 \mathrm{~mm}$ 
The teeth reported here differ from those previously described from Germany (Reinecke et al. 2011; Pollerspöck and Straube 2017). In those specimens, the apex of the crown is very acute and the apron is narrower. However, differences in the material described here could be related also to a taphonomic effect. Therefore, as the teeth are very abraded and lack diagnostic characters, our specimens can be only identified at the genus level.

Family Centrophoridae Bleeker, 1859

Genus Centrophorus Müller and Henle, 1837

Type species. Squalus granulosus Bloch and Schneider, 1801

Centrophorus granulosus (Bloch and Schneider, 1801)

Figure 3c, d

Material. Eleven lower antero-lateral teeth-SNSB-BSPG 2019 III-13, SNSB-BSPG 2019 III-14 (2 teeth), SNSBBSPG 2019 III-15 (8 teeth); and 3 upper lateral teethSNSB-BSPG 2019 III-16, SNSB-BSPG 2019 III-17 (2 teeth).

Description. The lower antero-lateral teeth are labio-lingually compressed with a broad and distally inclined cusp (Fig. 3c, d). The mesial edge is faintly sigmoidal and serrated, whereas the distal edge is slightly convex and smooth. The distal heel is notched and convex without any serrations. The apron is long and broader at its base with a rounded end. On the lingual face, a short uvula with a deep infundibulum is present just below its lower extremity. The distal part of the root is larger than the mesial one and displays some foramina. In labial view, the mesial part of the root displays a large foramen and has a concave contour. In upper lateral teeth, the crown is higher than broad. The mesial edge is slightly sigmoidal and serrated. The distal heel is short and strongly convex with weak serrations. The root is very abraded and covered by sediment. Apron, uvula and root foramina are not distinguishable.

Remarks. The genus Centrophorus is currently represented by 13 species with global distributions (Pollerspöck and Straube 2019). These mid- to deep-water sharks inhabit tropical to temperate environments (Compagno et al. 2005; White et al. 2013). The fossil record of Centrophorus extends back into the upper Cretaceous (Cappetta 2012). Early Miocene records of Centrophorus were reported from Austria (Pfeil 1983; Schultz 2013), Colombia (CarrilloBriceño et al. 2016a), Germany (Probst 1879; Fischli 1930; Barthelt et al. 1991; Scholz and Bienert 1992; Baier et al. 2004; Pollerspöck and Beaury 2014; Sach 2016; Pollerspöck and Straube 2017), Switzerland (Bolliger et al. 1995; Jost et al. 2016), Slovakia (Holec et al. 1995 as Squalus sp.) and the USA (Phillips et al. 1976).

According to Vialle et al. (2011), the serrated mesial cutting edge and the absence of folds on the uvula are the diagnostic characters that separate $C$. granulosus from other species. Thereby, these characters that are present in our material allow us to identify it at species level.

Genus Deania Jordan and Snyder, 1902

Type species. Deania eglantina Jordan and Snyder, 1902

Deania sp.

Figure 3e, f

Material. One lower tooth-SNSB-BSPG 2019 III-18.

Description. The lower tooth is labio-lingually compressed with a short, narrow and distally oriented cusp (Fig. 3e, f). The cutting edges are completely smooth. The mesial cutting edge is convex in its lower part and slightly straight in its upper part. The distal cutting edge is slightly convex. The distal heel is convex and serrated. The apron is short and broad, reaching the base of the root. In lingual view, the uvula is short. The root is short, abraded and covered with sediment; thus, the infundibulum and foramina are not distinguished.

Remarks. The genus Deania is currently represented by four species (D. calcea, D. hystricosa, D. profundorum and D. quadrispinosa) occurring in the Atlantic, Indian, and Pacific oceans, but not in the Mediterranean Sea (Compagno 1984a; Akhilesh et al. 2010). The fossil record of Deania extends back into the lower Paleocene (Cappetta 2012). Early Miocene records were only reported from Austria (Pfeil 1983; Schultz 2013; Pollerspöck et al. 2018), Germany (Pollerspöck and Straube 2017) and Switzerland (Bolliger et al. 1995). However, according to Reinecke et al. (2011), Deania also occurrs in different localities of the early Miocene in the Paratethys and Mediterranean seas.

Considering the narrow cusp and the smooth mesial cutting edge, the tooth described here can be unambiguously identified as belonging to the genus Deania. However, due to the lack of diagnostic characters and the small number of specimens available for this study, it is not possible to identify it at specific level.

Family Dalatiidae Gray, 1851

Genus Isistius Gill, 1864

Type species. Scymnus brasiliensis Quoy and Gaimard, 1824 
Isistius triangulus (Probst, 1879)

Figure $3 \mathrm{~g}$, h

Material. Two lower antero-lateral teeth-SNSB-BSPG 2019 III-19, SNSB-BSPG 2019 III-20.

Description. The crowns of the two antero-lateral teeth are abraded and the root is incomplete (Fig. $3 \mathrm{~g}$, h). The crown is labio-lingually compressed and triangular. The cutting edges are smooth and almost straight. The crown slightly overhangs the root distally and mesially. The root is high, flat and covered with sediment; thus, the median foramina cannot be distinguished.

Remarks. The genus Isistius is currently represented by three species: I. brasiliensis, I. labialis and I. plutodus (de Figueiredo and de Carvalho 2018). The cookie cutter shark (I. brasiliensis) has a wide geographic distribution in tropical and subtropical environments, whereas the largetooth cookie cutter shark (I. plutodus) has been reported from the Atlantic and Northwest Pacific oceans (Compagno 1984a; Compagno et al. 2005). The fossil record of $I$. triangulus ranges from the early Miocene to the early Pliocene (Cappetta 2012). Early Miocene records are from Austria (Schultz 2013), France (Cappetta 1970), Germany (Probst 1879, as Scymnus triangulus; von Ihering 1927; Barthelt et al. 1991; Pollerspöck and Beaury 2014; Sach 2016; Pollerspöck and Straube 2017), Hungary (Kocsis 2007), Portugal (Antunes and Jonet 1970), Slovakia (Holec et al. 1995) and Switzerland (Leriche 1927; Jost et al. 2016).

According to Laurito (1997, 1999), the fossil species $I$. triangulus can be distinguished from the extant I. brasiliensis and I. plutodus by its different crown shape. In I. triangulus, the crown edges form an equilateral triangle (CarrilloBriceño et al. 2014; Pérez and Marks 2017), whereas it is isosceles in I. brasiliensis and I. plutodus.

Order Squatiniformes Buen, 1926

Family Squatinidae Bonaparte, 1838

Genus Squatina Dumeril, 1806

Type species. Squalus squatina Linnaeus, 1758

\section{Squatina sp.}

Figure $4 a, b$

Material. Four lateral teeth-SNSB-BSPG 2019 III-21, SNSB-BSPG 2019 III-22 (two teeth), SNSB-BSPG 2019 III-23.

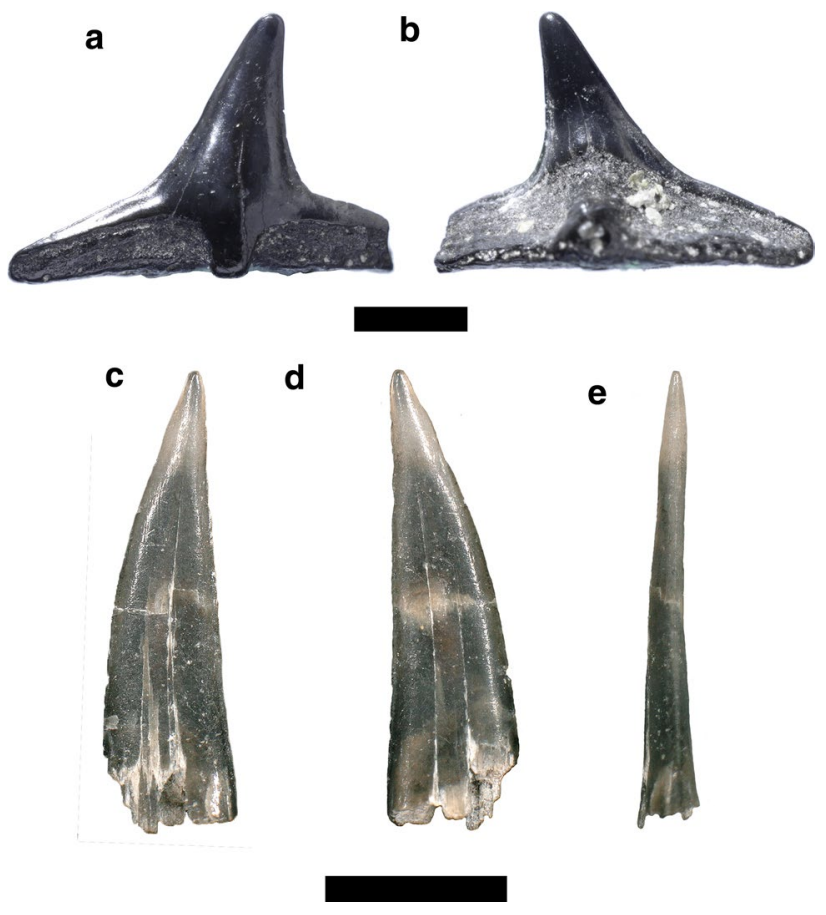

Fig. 4 Squatiniformes. a, b Squatina sp., lateral tooth, Pristiophoriformes. c-e Pristiophorus sp., rostral spine. Labial: a; lingual: b; dorsal: c; ventral: d; anterior: e. Scale bar $2 \mathrm{~mm}$

Description. The lateral teeth are broader than high (Fig. 4a, b). The crown is rather low, slender and distally inclined. The cutting edges are smooth. The mesial and distal heels are elongated and low with sharp cutting edges. In labial view, the apron is short and basally rounded. The mesial and distal crown-root boundaries are slightly concave. The lingual protuberance is massive with a well-developed foramen at its extremity. In profile view, the lingual crown face is slightly concave, whereas the labial crown face is convex. The root is high and broad in lingual view. In labial view, the root face is slightly straight basally.

Remarks. The genus Squatina is currently represented by 24 species with global distributions in temperate and tropical seas (Pollerspöck and Straube, 2019). In the Mediterranean Sea, Squatina is represented by the angel shark (S. squatina), the sawback angelshark (S. aculeata) (Serena 2005; Ebert and Stehmann 2013) and the smoothback angelshark (S. oculata) (Ergüden et al. 2019). The genus extends back to the Early Cretaceous (Klug and Kriwet 2013). Early Miocene records of Squatina were reported from Austria (Brzobohatý and Schultz 1971; Schultz 2013), Chile (Suarez et al. 2006; Villafaña et al. 2019), France (Cappetta 1970, 1973; Canevet 2011), Germany (Probst 1879; Lutzeier 1922; von Ihering 1927; Barthelt et al. 1991; Scholz and Bienert 1992; Baier et al. 2004; Reinecke et al. 2011; Pollerspöck and Beaury 2014; Sach 2016), Hungary (Kordos and Solt 1984; Kocsis 
a
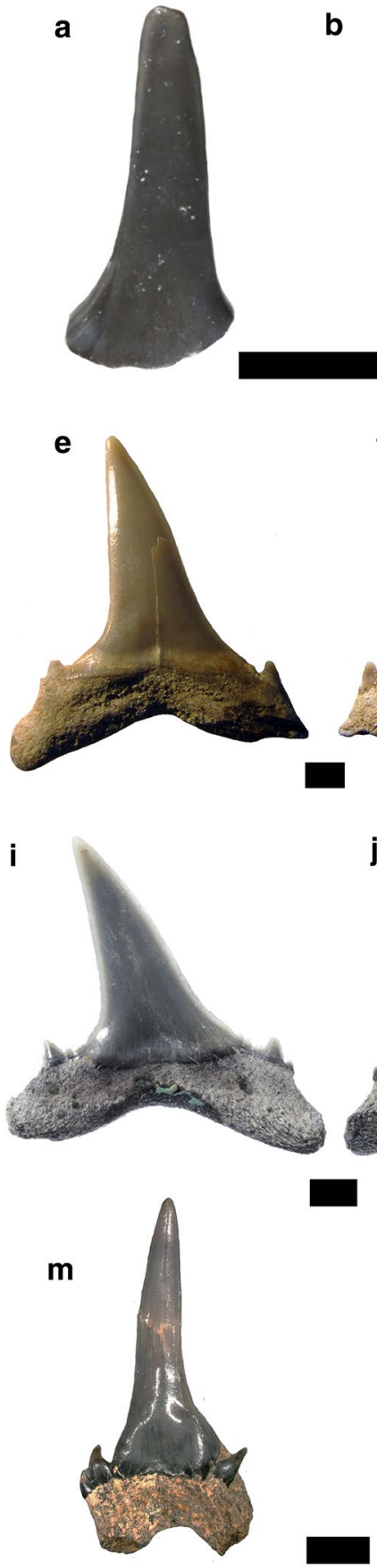

q

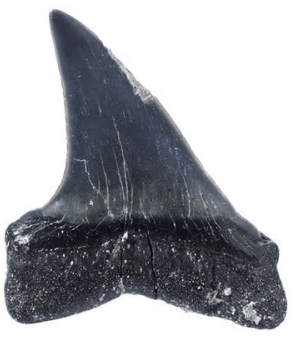

j

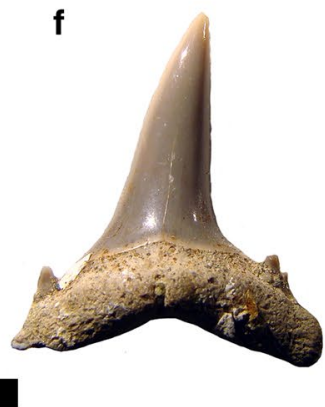

c
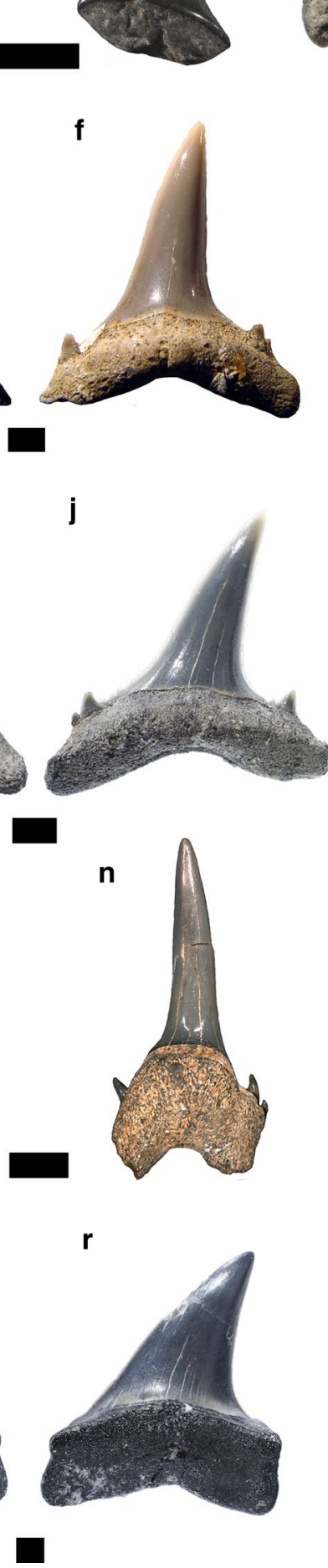

d
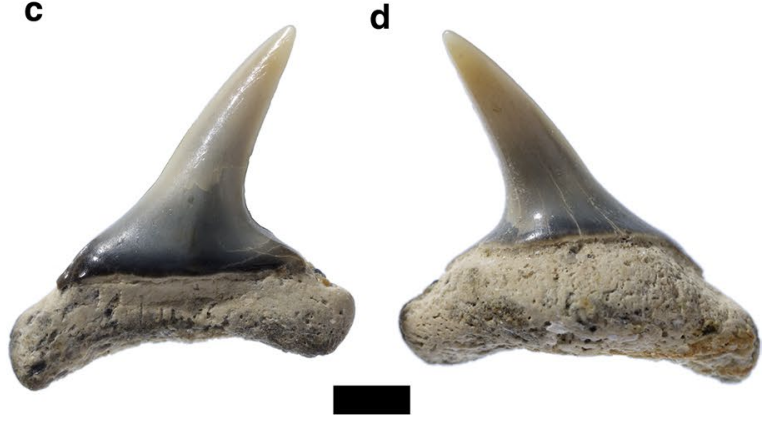

g

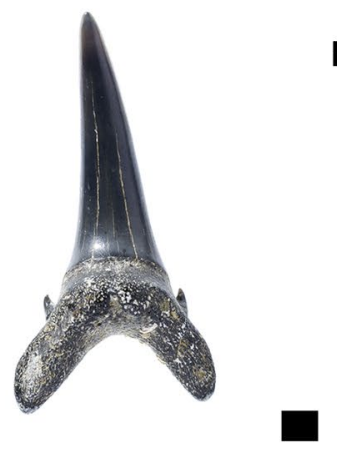

h

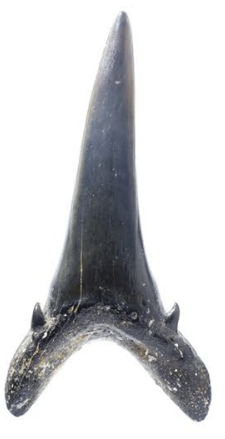

k

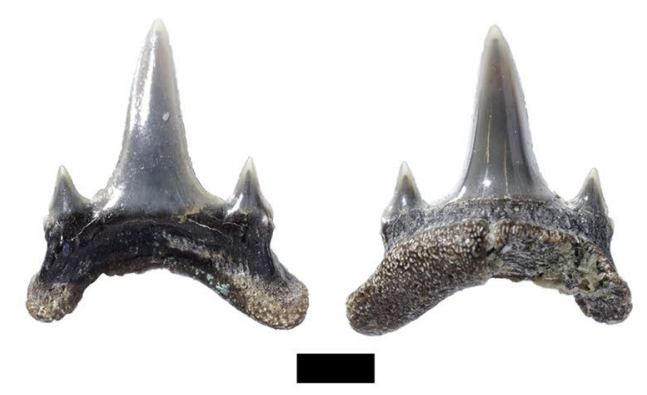

o

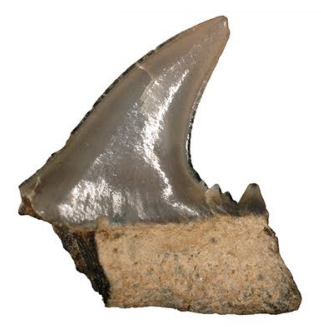

p

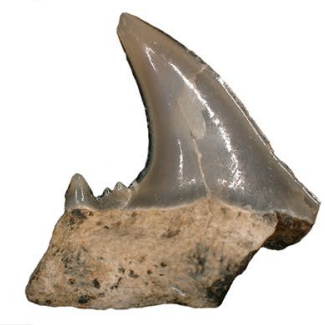

$\mathbf{S}$
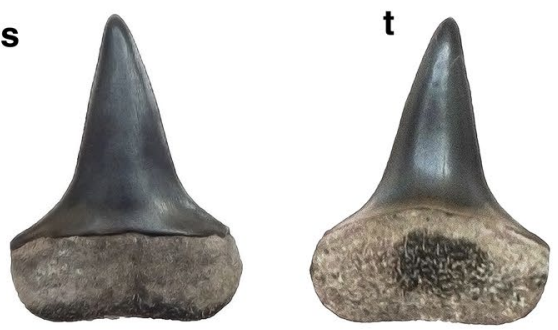
४Fig. 5 Lamniformes. a-d Mitsukurina lineata, a, b upper lateral tooth, Alopias exigua, c, d lower lateral teeth, e, f Araloselachus cuspidatus, $\mathbf{g}, \mathbf{l}$ Carcharias acutissima, $\mathbf{g}, \mathbf{h}$ upper lateral tooth, $\mathbf{i}, \mathbf{j}$ lower anterior tooth, $\mathbf{k}, \mathbf{l}$ lower latero-posterior tooth, $\mathbf{m}-\mathbf{p}$ Odontaspis molassica, q-t Carcharodon hastalis, $\mathbf{q}, \mathbf{r}$ upper lateral, lower. Labial: a, c, e, $\mathbf{g}, \mathbf{i}, \mathbf{l}, \mathbf{n}$; lingual: b, d, f, h, j, k, m. Scale bar $2 \mathrm{~mm}$

2007), Peru (Landini et al. 2019), Portugal (Antunes and Jonet 1970), Switzerland (Leriche 1927; Fischli 1930; Bolliger et al. 1995), Slovakia (Holec et al. 1995) and the USA (Phillips et al. 1976; Case 1980).

Order Pristiophoriformes Berg, 1958

Family Pristiophoridae Bleeker, 1859

Genus Pristiophorus Müller and Henle, 1837

Type species. Pristis cirratus Latham, 1794

\section{Pristiophorus sp.}

Figure 4c-e

Material. Two rostral spines-SNSB-BSPG 2019 III-24, SNSB-BSPG 2019 III-25.

Description. The rostral spines are abraded and the basal peduncle is missing (Fig. 4c-e). The enameloid cap is long, slender and dorso-ventrally flattened with smooth cutting edges. The enameloid is smooth and devoid of any ornamentation. The spine is slightly bent towards the rear.

Remarks. The genus Pristiophorus is currently represented by seven species that are distributed in temperate and subtropical regions (Compagno 2001). This genus is present in the western Pacific, western Central Atlantic, and Indian oceans, but not in the Mediterranean Sea (Compagno 1998; Last and Stevens 2009; Yearsley et al. 2008). The fossil record of Pristiophorus extends back to the lower Cretaceous (Cappetta 2012). Early Miocene records were reported from Australia (Fitzgerald 2004), Austria (Schultz 2013), Chile (Suarez et al. 2006; Villafaña et al. 2019), Colombia (Carrillo-Briceño et al. 2016a), Germany (von Ihering 1927; Barthelt et al. 1991; Reinecke et al. 2011; Pollerspöck and Beaury 2014; Sach 2016; Pollerspöck and Straube 2017), Slovakia (Underwood and Schlögl 2013) and Switzerland (Fischli 1930; Jost et al. 2016).

The rostral spine reported here can be unambiguously identified as belonging to the genus Pristiophorus. According to Underwood and Schlögl (2013) and Engelbrecht et al. (2017), Pristiophorus species erected on the sole basis of rostral teeth should be considered as nomina dubia because of the lack of specific diagnostic characters. Thereby, the oral teeth should be used as comparative material instead of rostral spines. For this reason, identification at specific level of the single Pristiophorus spine reported here is not possible.

Order Lamniformes Berg, 1937

Family Mitsukurinidae Jordan, 1898

Genus Mitsukurina Jordan, 1898

Type species. Mitsukurina owstoni Jordan, 1898

Mitsukurina lineata (Probst, 1879)

Figure 5a, b

Material. Two upper anterior teeth-SNSB-BSPG 2019 III26, SNSB-BSPG 2019 III-27.

Description. The teeth have a high, slender and in profile view slightly sigmoidal cusp with a broad base (Fig. 5a, b). In labial view, the crown surface is almost completely smooth with only few short folds at its base. In lingual view, strong longitudinal folds extend from its base to the middle part of the cusp. Both faces of the crown are slightly convex transversely. The root is missing.

Remarks. The genus Mitsukurina is represented today only by the goblin shark $M$. owstoni, occurring in the Atlantic, Pacific and western Indian oceans, but absent in the southeastern Pacific and Mediterranean Sea (Last and Stevens 1994; Compagno 2001). The fossil record of Mitsukurina lineata dates back to the early Miocene of Europe (Cappetta 2012).

Early Miocene records of this species are from Austria (Schultz 2013), France (Joleaud 1912; Cappetta 1975), Germany (Probst 1879, as Lamna lineata; Lutzeier 1922; Barthelt et al. 1991; Scholz and Bienert 1992; Baier et al. 2004; Höltke 2014; Pollerspöck and Beaury 2014; Sach 2016), Hungary (Kocsis 2007), Slovakia (Holec et al. 1995) and Switzerland (Bolliger et al. 1995; Jost et al. 2016).

Family Alopiidae Bonaparte, 1838

Genus Alopias Rafinesque, 1810

Type species. Alopias macrourus Rafinesque, 1810

Alopias exigua (Probst, 1879)

Figure 5c, d

Material. Five lower lateral teeth-SNSB-BSPG 2019 III28, SNSB-BSPG 2019 III-29. 
Description. The teeth have a slender, acute and distally inclined cusp with a broad base (Fig. 5c, d). The mesial cutting edge is rather straight, whereas the distal one is strongly concave. Both cutting edges are sharp and reach the base of the crown. The labial crown face is almost flat, whereas the lingual face is convex. Both faces are devoid of any ornamentation. In labial view, the crown/root boundary is straight. A narrow and rather straight crown neck separates the labial crown face from the root. The root lobes are short and well divergent with rounded extremities.

Remarks. The genus Alopias is currently represented by three species: A. pelagicus, A. superciliosus, and A. vulpinus. The pelagic thresher (A. pelagicus) is distributed in the Indo-Pacific and eastern Pacific. The bigeye thresher ( $A$. superciliosus) and the thresher (A. vulpinus) have a wide distribution in tropical and temperate oceans, including the Mediterranean Sea (Last and Stevens 1994; Compagno et al. 2005). The fossil record of A. exigua ranges from the early Oligocene to the middle Miocene (Cappetta 2012). Early Miocene records of A. exigua were reported from Austria (Brzobohatý and Schultz 1971), France (Cappetta 1970), Germany (von Ihering 1927; Barthelt et al. 1991; Baier et al. 2004; Reinecke et al. 2011; Höltke 2014; Pollerspöck and Beaury 2014; Sach 2016) and Hungary (Kordos and Solt 1984; Kocsis 2007).

The extinct A. exigua can be distinguished from the extant species by its narrower cusp and lower root. The teeth described here match perfectly with those reported from the early Miocene of northern Germany by Reinecke et al. (2011).

Family Odontaspididae Müller and Henle, 1838

Genus Araloselachus Glikman, 1964

Type species. Araloselachus agespensis Glikman, 1964

Araloselachus cuspidatus (Agassiz, 1843)

Figure 5e, $\mathrm{f}$

Material. Six upper antero-lateral teeth-SNSB-BSPG 2019 III-30, SNSB-BSPG 2019 III-31, SNSB-BSPG 2019 III-32 (four teeth); and one anterior tooth-SNSB-BSPG 2019 III-33.

Description. The upper antero-lateral teeth have a triangular and distally inclined cusp (Fig. 5e, f). The mesial cutting edge is slightly concave at its base and convex at its upper part. In profile view, the crown is rather straight. The distal cutting edge is concave at its base and straight in its medial and upper parts. A pair of low lateral cusplets are present, which are triangular and devoid of any ornamentation. The root is low with short and well-separated lobes.

The anterior tooth (not figured) is very abraded and part of the apex is missing. The crown is triangular, high and robust. In profile view, the cusp also is straight. The labial crown/root boundary is concave and the labial face overhangs the root in its medial part. The enameloid surface is completely smooth on both crown faces. The lateral cusplets are broken. The root is high with well-separated and long lobes.

Remarks. A. cuspidatus is common in Oligocene and Miocene fossiliferous sites (Cappetta 2012). Early Miocene records are from Australia (Pledge 1967), Austria (Brzobohatý and Schultz 1971), France (Cappetta 1970, 1973; Goedert et al. 2017), Germany (Barthelt et al. 1991, as Synodontaspis cuspidata; Sach and Heizmann 2001; Sach 2016, as Carcharias cuspidatus), Hungary (Kocsis 2007, as Carcharias cuspidatus), Italy (Marsili et al. 2007), Portugal (Zbyszewski 1949), Slovakia (Holec et al. 1995), Switzerland (Bolliger et al. 1995, as Carcharias cuspidatus) and the USA (Case 1980; Kent 2018).

According to Cappetta (2012), the genus Araloselachus has sufficient morphological characters to be separated from other odontaspid genera. In A. cuspidatus, features of the anterior teeth are used to separate the species from other odontaspids. In this species, the teeth are more robust and stronger, the crown is straight in profile view and the enameloid surface is completely smooth. The teeth reported herein are similar to those described from the middle Miocene of Hungary (Szabó and Kocsis 2016).

Genus Carcharias Rafinesque, 1810

Type species. Carcharias taurus Rafinesque, 1810

Carcharias acutissimus (Agassiz, 1843)

Figure $5 \mathrm{~g}-1$

Material. 44 anterior teeth-SNSB-BSPG 2019 III-34, SNSB-BSPG 2019 III-35 (4 teeth), SNSB-BSPG 2019 III-36 (39 teeth); 31 upper lateral teeth-SNSB-BSPG 2019 III-37, SNSB-BSPG 2019 III-38 (5 teeth), SNSB-BSPG 2019 III-39 (25 teeth); and 20 lower lateral teeth-SNSB-BSPG 2019 III-40, SNSB-BSPG 2019 III-41 (5 teeth), SNSB-BSPG 2019 III-42 (14 teeth).

Description. The anterior teeth show an elongated and slender cusp with a strong sigmoidal profile (Fig. 5g, h). The cutting edges are smooth and do not reach the base of the crown. The crown/root boundary is strongly concave in labial view. One to two pairs of sharp lateral cusplets are present, which are lingually bent. The root is high with two long 
and well-separated lobes. The lingual protuberance displays a well-developed nutritive groove.

In the upper lateral teeth, the crown is triangular and distally inclined (Fig. 5i, j). In profile view, the crown is straight. In lingual view, the enameloid surface shows weakly vertical folds at its base. The crown/root boundary is slightly concave in labial view.

The lower lateral teeth show a straight, rather low and triangular cusp (Fig. 5k, 1). There are one to three pairs of lateral cusplets, which are high and triangular in labial view. The crown/root boundary is strongly concave. The root is low with two short and well-separated lobes. The lingual protuberance is bifurcated with a nutritive groove.

Remarks. The fossil record of C. acutissimus ranges from the Oligocene to the Pliocene (Cappetta 2012). Early Miocene records were reported from Austria (Schultz 2013), Costa Rica (Laurito et al. 2014), France (Chevalier 1961; Cappetta 1970, as Odontaspis acutissima), Germany (Barthelt et al. 1991, as Synodontaspis acutissima; Baier et al. 2004; Höltke 2014), Hungary (Kordos and Solt 1984, as Odontaspis acutissima; Kocsis 2007), Italy (Marsili et al. 2007), Slovakia (Holec et al. 1995, as Synodontaspis acutissima), Switzerland (Leriche 1927; Fischli 1930) and the USA (Case 1980, as Odontaspis acutissima). Although teeth of C. taurus share some similarities with those of $C$. acutissimus (Arambourg 1952), no detailed studies about their morphological characters have been carried out so far. The teeth described here are similar to those from the early Miocene of Italy (Marsili et al. 2007) and the middle Miocene of Hungary (Szabó and Kocsis 2016).

Genus Odontaspis Agassiz, 1843

Type species. Squalus ferox Risso, 1810

Odontaspis molassica (Probst, 1879)

Figure $5 \mathrm{~m}-\mathrm{p}$

Material. Two anterior teeth-SNSB-BSPG 2019 III-43, SNSB-BSPG 2019 III-44; and two upper antero-lateral teeth-SNSB-BSPG 2019 III-45, SNSB-BSPG 2019 III-46.

Description. The anterior teeth have a high and slender cusp with a slightly sigmoidal profile (Fig. $5 \mathrm{~m}, \mathrm{n}$ ). The enameloid surface is completely smooth on both cusp faces. The two pairs of lateral cusplets are high and sharp. The cutting edges are smooth and do not reach the base of the crown. The lingual protuberance is very strong and it is divided by a nutritive groove. The crown/root boundary is slightly concave. The root is high and massive in lingual view. Both lobes are well separated, but lack their extremities.
The upper antero-lateral tooth has a triangular cusp, which is strongly distally oriented (Fig. 5o, p). Three pairs of lateral cusplets are present distally. The mesial cutting edge is convex, whereas the distal one is concave. The crown/root boundary is straight in both faces. The root is rather low and straight. The mesial part of the crown and root is broken.

Remarks. Odontaspis molassica is not very common in the fossil record. Early Miocene finds are from France (Cappetta 1970, 1973), Germany (Probst 1879; Barthelt et al. 1991; Baier et al. 2004, Sach 2016) and Portugal (Antunes et al. 1981).

According to Reinecke et al. (2011), the anterior teeth of $O$. molassica can be distinguished from Carcharias species (e.g. C. gustrowensis) by their more slender and higher cusp. Additionally, the crown surface in $O$. molassica is always smooth on both cusps faces in lateral and anterior teeth. Finally, the teeth described here have a slightly concave to straight crown/root boundary in labial view. All these characters were originally highlighted by Probst (1879) and later confirmed by Bracher and Unger (2007).

Family Lamnidae Müller and Henle, 1838

Genus Carcharodon Müller and Henle, 1838

Type species. Squalus carcharias Linnaeus, 1758

Carcharodon hastalis (Agassiz, 1838)

Figure $5 \mathrm{q}-\mathrm{t}$

Material. One upper lateral-SNSB-BSPG 2019 III-47; and one lower lateral tooth-SNSB-BSPG 2019 III-48.

Description. The upper lateral tooth displays a triangular cusp with smooth cutting edges (Fig. 5q, r). The mesial cutting edge is slightly convex, whereas the distal one is concave. The enameloid surface is completely smooth and the labial face is flat. The root is high with short lobes.

In the lower lateral tooth, the cusp is also triangular, but straight and narrower than the upper tooth (Fig. $5 \mathrm{~s}$, t). The basal part of the mesial and distal edges is concave. The root is high and flat with a straight basal part, probably eroded.

Remarks. The taxonomic classification of $C$. hastalis has been widely debated in the last years (see Purdy et al. 2001; Cappetta 2012; Cione et al. 2012; Ehret et al. 2012; Boessenecker et al. 2019). Ehret et al (2012) proposed a reconstruction of the evolutionary history of the genus Carcharodon based on dental characters shared between the fossil and extant species. According to these authors, the non-serrated C. hastalis evolved into the semi-serrated C. hubbelli and then to the fully serrated C.carcharias. Therefore, the 
evolutionary transition from $C$. hastalis to $C$. carcharias occurred within a span of 6.9-5.3 Ma. (Long et al. 2014; Boessenecker et al. 2019).

The fossil record of $C$. hastalis ranges from the Miocene to the Pliocene (Cappetta 2012). Early Miocene records were reported from Argentina (Scasso and Castro 1999), Austria (Schultz 2013), Chile (Suarez et al. 2006), Egypt (Cook et al. 2010), France (Cappetta 1970), Germany (Barthelt et al. 1991, as Isurus hastalis; Baier et al. 2004; Reinecke et al. 2011); Sach 2016), Hungary (Kordos and Solt 1984, as Isurus hastalis; Kocsis 2007), Italy (Marsili et al. 2007), Peru (Bianucci et al. 2018; Landini et al. 2019, as Cosmopolitodus hastalis), Slovakia (Koch 1904, as Isurus hastalis), Spain (Vicens and Rodríguez-Perea 2003, as Isurus hastalis), Switzerland (Leriche 1927) and the USA (Purdy 1998; Purdy et al. 2001; Kent 2018).

Order Carcharhiniformes Compagno, 1973

Family Carcharhinidae Jordan and Evermann, 1896

Genus Carcharhinus de Blainville, 1816

Type species. Carcharias melanopterus Quoy and Gaimard, 1824

Carcharhinus priscus (Agassiz, 1843)

Figure 6a, d

Material. 25 upper antero-lateral teeth-SNSB-BSPG 2019 III-49, SNSB-BSPG 2019 III-50 (6 teeth), SNSB-BSPG 2019 III-51 (18 teeth); and 14 lower teeth-SNSB-BSPG 2019 III-52, SNSB-BSPG 2019 III-53 (13 teeth).

Description. The upper antero-lateral teeth have a broad and triangular cusp, which is distally inclined (Fig. 6a, b). The cutting edges are continuously serrated along the main cusp and on the heels. The root is high in lingual view with wellseparated root lobes. A shallow nutritive groove is present in the lingual root protuberance.

In the lower teeth, the cusp is narrower and also distally inclined with broad lateral heels (Fig. 6c, d). The cutting edges are faintly serrated in the main cusp and heels. In lingual view, the root is mesio-distally extended with a distinct furrow and foramen. The basal face of the root is straight basally.

Remarks. Carcharhinus priscus is one the most common species reported from the Neogene of the Mediterranean Sea and Paratethys (Cappetta 2012; Szabó and Kocsis 2016), but might represent a wastebasket taxon. This fossil species range from the early Miocene to Pliocene according to Reinecke et al. (2011). Early Miocene records were reported from Austria (Schultz 2013), Brazil (Toledo 1989), France
(Cappetta 1970, 1973), Germany (Barthelt et al. 1991; Scholz and Bienert 1992; Baier et al. 2004; Reinecke et al. 2011; Pollerspöck and Beaury 2014; Sach 2016), Hungary (Kocsis 2007), Pakistan (Welcomme et al. 1997), Portugal (Antunes et al. 1981), Saudi Arabia (Thomas 1982), Slovakia (Holec et al. 1995), Spain (Vicens and Rodríguez-Perea 2003), Switzerland (Bolliger et al. 1995) and the USA (Case 1980; Kent 2018).

According to Maisch et al. (2018), the serrated cutting edges and the absence of a notch separating the main cusp and the tooth shoulders allow to separate $C$. priscus from other species of Carcharhinus. The teeth reported herein share similarities with those from the early Miocene of Northern Germany (see Reinecke et al. 2011) and are therefore assigned to this species.

\section{Carcharhinus sp.}

Figure 6e, $\mathrm{f}$

Material. 14 upper antero-lateral teeth-SNSB-BSPG 2019 III-54, SNSB-BSPG 2019 III-55 (13 teeth); and three lower antero-lateral teeth-SNSB-BSPG 2019 III-56.

Description. The upper antero-lateral teeth display a triangular and distally inclined cusp (Fig. 6e, f). The cutting edges are completely smooth, probably eroded. The heels are low and slightly convex in labial view. The root is high in lingual view with well-separated lobes. In the lower antero-lateral teeth, the crown is rather low and upright. The cutting edges are also smooth along the cusp and crown shoulders. The root is low with well-separated lobes.

Remarks. The genus Carcharhinus is currently represented by 35 species with global distributions (Pollerspöck and Straube 2019). In the Mediterranean Sea, the sandbar shark ( $C$. plumbeus), the bignose shark (C. altimus), the copper shark (C. brachyurus), the silky shark ( $C$. falciformis), the spinner shark ( $C$. brevipinna), the blacktip shark (C. limbatus), blacktip reef shark (C. melanopterus) and the dusky shark (C. obscurus) have been reported up to now (Garibaldi and Relini 2012; Froese and Pauly 2019). The fossil record of Carcharhinus extends back to the middle Eocene (Kriwet 2005; Cappetta 2012; Underwood and Gunter 2012). Early Miocene records of Carcharhinus were widely reported from Europe and America (Cappetta 1970, 2012; Case 1980; Barthelt et al. 1991; Suarez et al. 2006; Reinecke et al. 2011; Schultz 2013).

Genus Galeocerdo Müller and Henle, 1837

Type species. Squalus arcticus Faber, 1829

Galeocerdo aduncus Agassiz, 1843

Figure $6 \mathrm{~g}-\mathrm{j}$ 

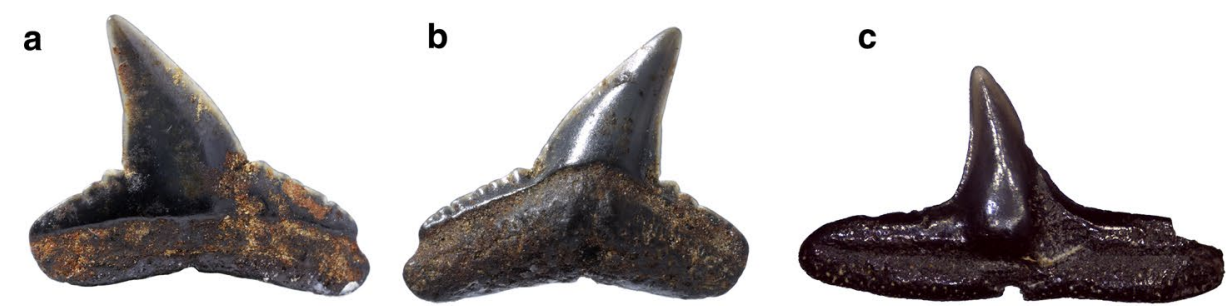

d
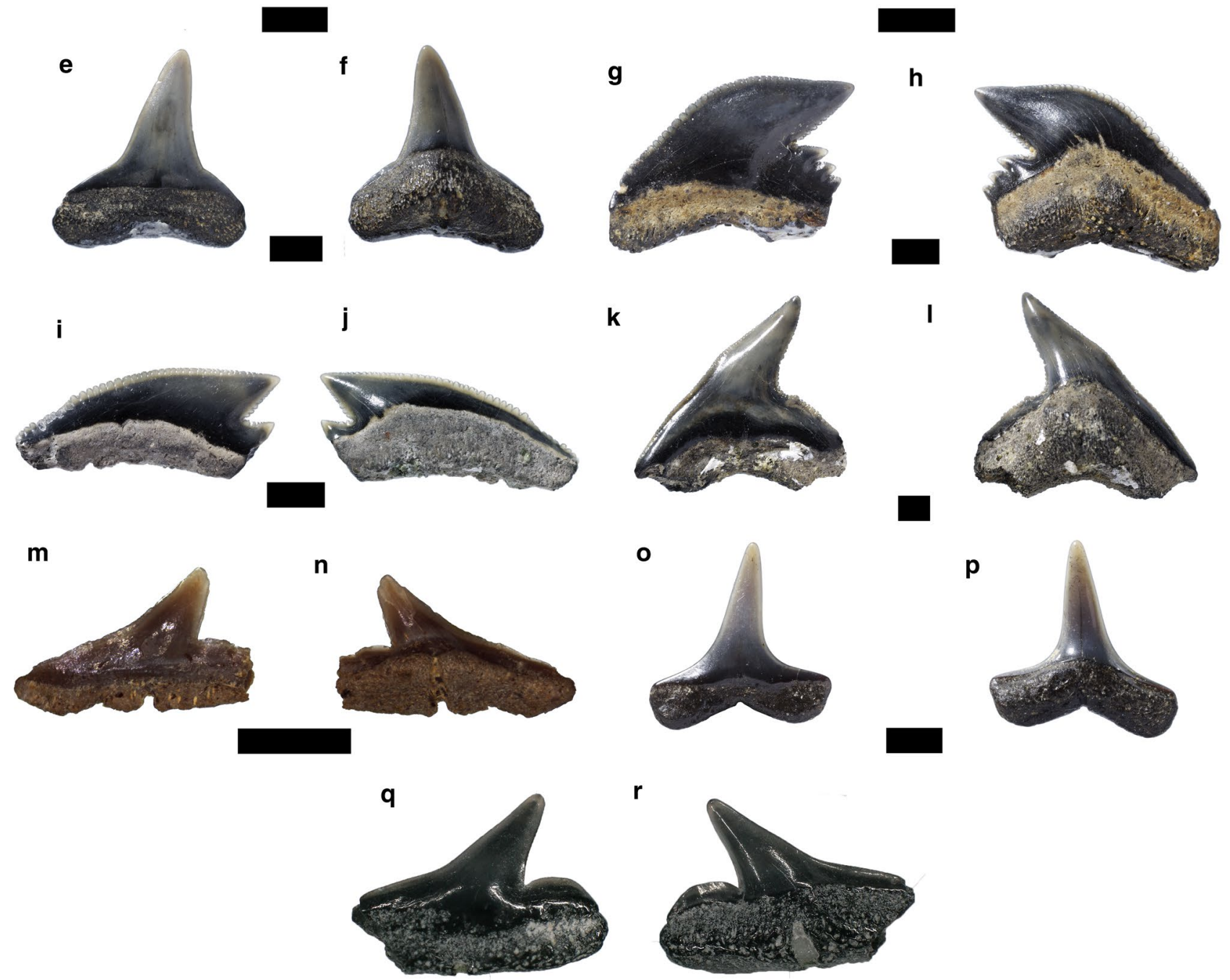

$\mathbf{r}$

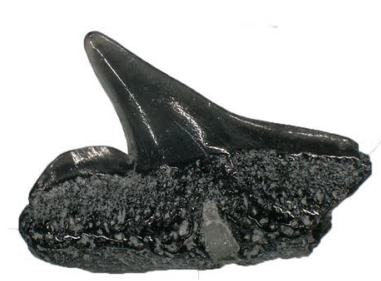

Fig. 6 Carcharhiniformes. a-d Carcharhinus priscus, a, b upper antero-lateral tooth, c, d lower antero-lateral tooth, e, f Carcharhinus sp., g-j Galeocerdo aduncus, $\mathbf{k}, \mathbf{l}$ Physogaleus contortus, $\mathbf{m}, \mathbf{n}$

Rhizoprionodon fischeri, o, p Isogomphodon acuaris, q, r Sphyrna sp. Labial: a, c, e, g, i, k, m, o; lingual: b, d, f, h, j, l, n, p. Scale bar $2 \mathrm{~mm}$

Material. Eight antero-lateral teeth-SNSB-BSPG 2019 III57, SNSB-BSPG 2019 III-58, SNSB-BSPG 2019 III-59 (six teeth); and one posterior tooth-SNSB-BSPG 2019 III-60.

Description. The antero-lateral teeth have a triangular and broad cusp, which is strongly distally inclined (Fig. 6g, h).
The mesial cutting edge is long and sigmoidal, whereas the distal one is short and slightly convex. Both cutting edges are strongly serrated from the base to the middle of the cusp, being only faintly serrated in the apex. The distal heel is high and strongly serrated. The root is very high in lingual view and low in labial face. 
The posterior tooth is broader than high (Fig. 6i, j). The crown is low, triangular and strongly distally bent. The mesial cutting edge is convex, whereas the distal one is straight. Both cutting edges are serrated. The distal heel is short, low and also serrated. The root is higher than the crown in lingual view.

Remarks. Galeocerdo aduncus is common in Miocene deposits (Cappetta 2012). Early Miocene records were reported from Austria (Schultz 2013; Pollerspöck et al. 2018), France (Cappetta 1970), Germany (Probst 1879; Lutzeier 1922; Barthelt et al. 1991; Scholz and Bienert 1992; Baier et al. 2004; Reinecke et al. 2011; Sach 2016), Hungary (Kordos and Solt 1984; Kocsis 2007), Italy (Marsili et al. 2007), Malta (Ward and Bonavia 2001), Portugal (Antunes et al. 1981), Peru (Bianucci et al. 2018; Landini et al. 2019), Slovakia (Holec et al. 1995), Spain (Vicens and RodríguezPerea 2003; Mas 2009), Switzerland (Leriche 1927; Holec et al. 1995) and the USA (Purdy 1998; Kent 2018).

Genus Physogaleus Cappetta, 1980

Type species. Trigonodus secundus Winkler, 1876

\section{Physogaleus contortus (Gibbes, 1849)}

Figure 6k, 1

Material. One antero-lateral tooth-SNSB-BSPG 2019 III-61.

Description. The tooth displays a slender and distally inclined cusp (Fig. 6k, 1). The cutting edges are weakly serrated along the cusp and distal heel. The distal heel is low and convex. The root is high in lingual view and low in labial view. The root/crown boundary is strongly convex in lingual view, whereas it is slightly concave in labial view. Both root lobes are short and their extremities are missing.

Remarks. According to Reinecke et al. (2011), the fossil record of $P$. contortus ranges from the Oligocene to the middle Miocene. Early Miocene records were reported from Italy (Marsili et al. 2007), Germany (Reinecke et al. 2011), Hungary (Kocsis 2007, as Galeocerdo contortus), Panama (Pimiento et al. 2013), Peru (Bianucci et al. 2018; Landini et al. 2019) and the USA (Case 1980, as Galeocerdo contortus; Kent 2018).

Teeth of G. contortus have been confused often with lower teeth of G. aduncus. We follow the opinion of Purdy et al. (2001) and Reinecke et al. (2011), considering the aduncus and contortus morphotypes as belonging to different genera based on substantial differences between their dental characters.
Genus Rhizoprionodon Whitley, 1929

Type species. Carcharias (Scoliodon) crenidens Klunzinger, 1880

Rhizoprionodon sp.

Figure 6m, n

Material. Two antero-lateral teeth-SNSB-BSPG 2019 III62, SNSB-BSPG 2019 III-63.

Description. Both teeth are abraded and part of the distal region is missing (Fig. $6 \mathrm{~m}, \mathrm{n}$ ). The cusp is triangular and distally inclined with a flared base. The mesial cutting edge is slightly concave, whereas the distal one is straight. The distal heel is low and convex. The cutting edges are smooth along the cusp and distal heel. In lingual view, the root is high and shows a strong protuberance that is separated by a transverse nutritive groove.

Remarks. The genus Rhizoprionodon is currently represented by seven species occurring in temperate and tropical regions (Compagno 1984b). However, the genus is absent in the Mediterranean Sea. The fossil record of Rhizoprionodon extends back to the early Eocene (Cappetta 2012). Early Miocene records were reported from Austria (Schultz 2013), Germany (Barthelt et al. 1991; Baier et al. 2004; Reinecke et al. 2011; Pollerspöck and Straube 2017), Malta (Ward and Bonavia 2001), Switzerland (Bolliger et al. 1995) and the USA (Case 1980; Kent 2018).

According to Reinecke et al. (2011), Rhizoprionodon species show very similar dental characters and their identification at specific level is difficult. For this reason, we only identify our specimens at generic level.

Genus Isogomphodon Gill, 1862

Type species. Carcharias (Prionodon) oxyrhynchus Valenciennes, 1839

Isogomphodon acuarius (Probst, 1879)

Figure 6o, $\mathrm{p}$

Material. One lower lateral tooth-SNSB-BSPG 2019 III-64.

Description. The cusp is rather high and slightly distally inclined (Fig. 6o, p). The mesial and distal heels are low and mesio-distally extended. The cutting edges are smooth along the cusp and heels. The enameloid surface is completely smooth in both faces. The root is high in lingual view 
with a V-shaped basal face. The lobes are long with rounded extremities.

Remarks. The fossil record of I. acuarius ranges from early Miocene to the late Miocene (Cappetta 2012). Early Miocene records were reported from Costa Rica (Laurito 1999), France (Lalai, 1986), France (Cappetta 1970, as Aprionodon acuarius), Germany (Barthelt et al. 1991; Baier et al. 2004; Sach 2016), the USA (Case 1980), Switzerland (Bolliger et al. 1995) and Venezuela (Carrillo-Briceño et al. 2016b). The tooth described herein is similar to those from the early Miocene of Venezuela (Carrillo-Briceño et al. 2016b) and the middle Miocene of France (Vialle et al. 2011).

Family Sphyrnidae Gill, 1872

Genus Sphyrna Rafinesque, 1810

Type species. Squalus zygaena Linnaeus, 1758

\section{Sphyrna sp.}

Figure 6q, r

Material. Seven lower lateral teeth-SNSB-BSPG 2019 III65, SNSB-BSPG 2019 III-66 (six teeth).

Description. The teeth have a low and distally inclined cusp (Fig. 6q, r). The mesial cutting edges are slightly concave at their bases, but straight at their upper part. The distal heel is rather high and strongly convex. The cutting edges are smooth along the cusp and distal heel. The cusp and the distal heel are separated by a notch. The root is high and displays a vertical nutritive groove.

Remarks. The genus Sphyrna is currently represented by nine species occurring in tropical and temperate seas (Compagno 1984b). The scalloped hammerhead (S. lewini), the great hammerhead (S. mokarran), the smalleye hammerhead ( $S$. tudes) and the smooth hammerhead (S. zygaena) are known from the present-day Mediterranean Sea (Compagno 1998). The genus Sphyrna extends back to the lower Oligocene (Cappetta 2012). Early Miocene records are from Austria (Schultz 1998), Colombia (Carrillo-Briceño et al. 2016a), France (Cappetta 1970), Germany (Barthelt et al. 1991; Reinecke et al. 2011), Hungary (Kordos and Solt 1984; Kocsis 2007), Malta (Ward and Bonavia 2001), Panama (Gillette 1984), Peru (Bianucci et al. 2018; Landini et al. 2019), Portugal (Antunes et al. 1981), Switzerland (Leriche, 1927), Venezuela (Carrillo-Briceño et al. 2016b) and the USA (Purdy 1998).

Reinecke et al. (2011) described S. laevissima and S. integra from the early Miocene of northern Germany. In the described lower antero-lateral teeth of $S$. integra, the crown is broader and the distal heel is straight or faintly convex. In S. laevissima, the crown is triangular and the distal heel is oblique. Therefore, these species show dental characters that differ from those of the specimens described here. However, as the few teeth reported here are very abraded and only represent lower teeth, we prefer to identify them only at generic level until more material is available.

Family Scyliorhinidae Gill, 1862

Genus Scyliorhinus de Blainville, 1816

Type species. Squalus canicula Linnaeus, 1758

Scyliorhinus fossilis (Leriche, 1927)

Figure $7 \mathrm{a}-\mathrm{d}$

Material. Twelve anterior teeth-SNSB-BSPG 2019 III-67, SNSB-BSPG 2019 III-68 (11 teeth); and 12 lateral teethSNSB-BSPG 2019 III-69, SNSB-BSPG 2019 III-70 (8 teeth), SNSB-BSPG 2019 III-71 (3 teeth).

Description. The anterior teeth have a straight and slender cusp with a broader base (Fig. 7a, b). There is a pair of small, low and slightly divergent lateral cusplets, which are separated from the main cusp by a notch. A second, very incipient pair of lateral cusplets are developed at the outermost margins of the crown. Labially, strong vertical folds are present along the mesial and distal margins of the crown, extending from the crown/root boundary towards the base of the first pair of lateral cusplets. Lingually, short and closely spaced ridges are present below the lateral cusplets reaching up to the middle of the first pair of lateral cusplets and to the apex of the second pair. The cutting edges are well developed and continuous between the lateral cusplets and main cusp. The root is abraded and only the well-developed lingual protuberance is partially preserved.

In lateral teeth, the cusp is low and strongly distally inclined (Fig. 7c, d). In labial view, less pronounced folds are present along the distal and mesial margins. The root is well preserved, showing separated lobes with rounded extremities in labial view. A deep vertical nutritive groove is present on the lingual face of the root.

Remarks. Teeth of S. fossilis were reported from Miocene deposits of the Paratethys and Mediterranean regions. This species also occurs in the upper Marine Molasse of the Molasse Basin (Barthelt et al. 1991; Pfeil 1991; Reinecke et al. 2011; Schultz 2013). Additionally, it was described from the Miocene (Aquitanian to Messinian) of Switzerland, southern France, and Portugal (Leriche 1927; Antunes and Jonet 1970; Cappetta 1970, 2006; Jost et al. 2016). 

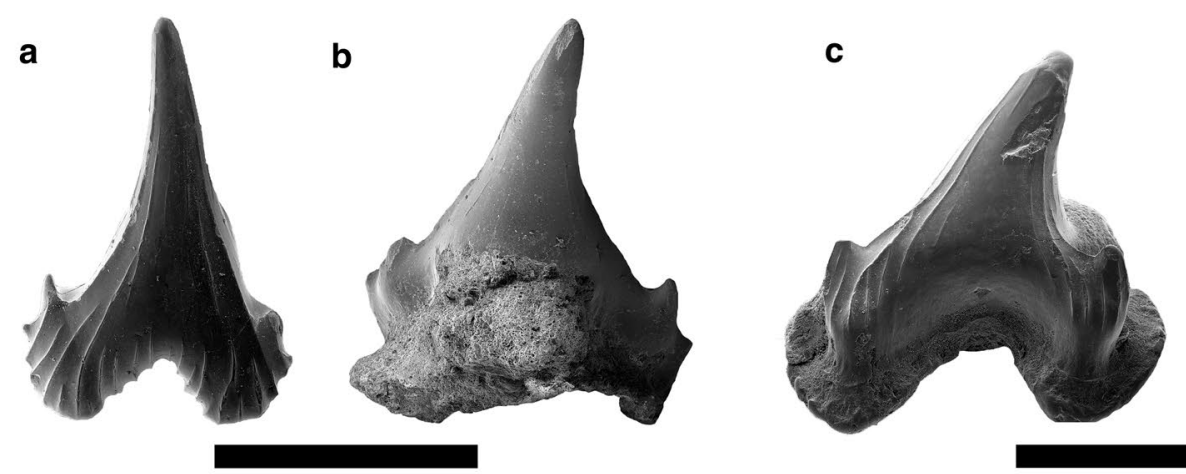

d

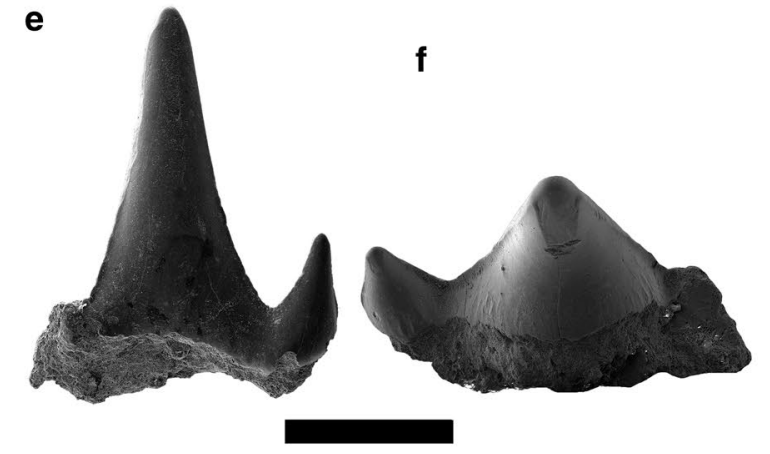

g

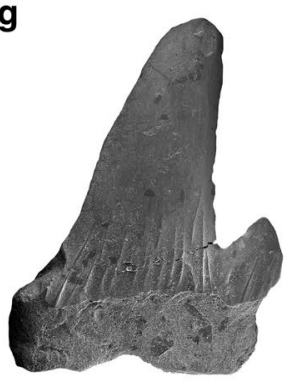

$\mathbf{h}$

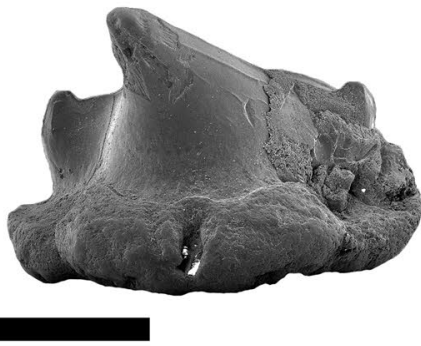

j

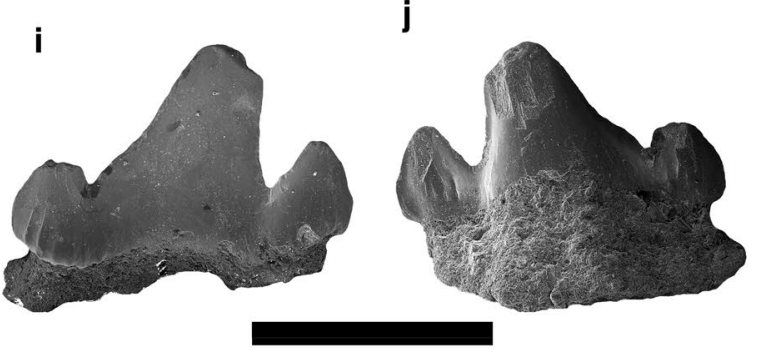

$\mathbf{k}$
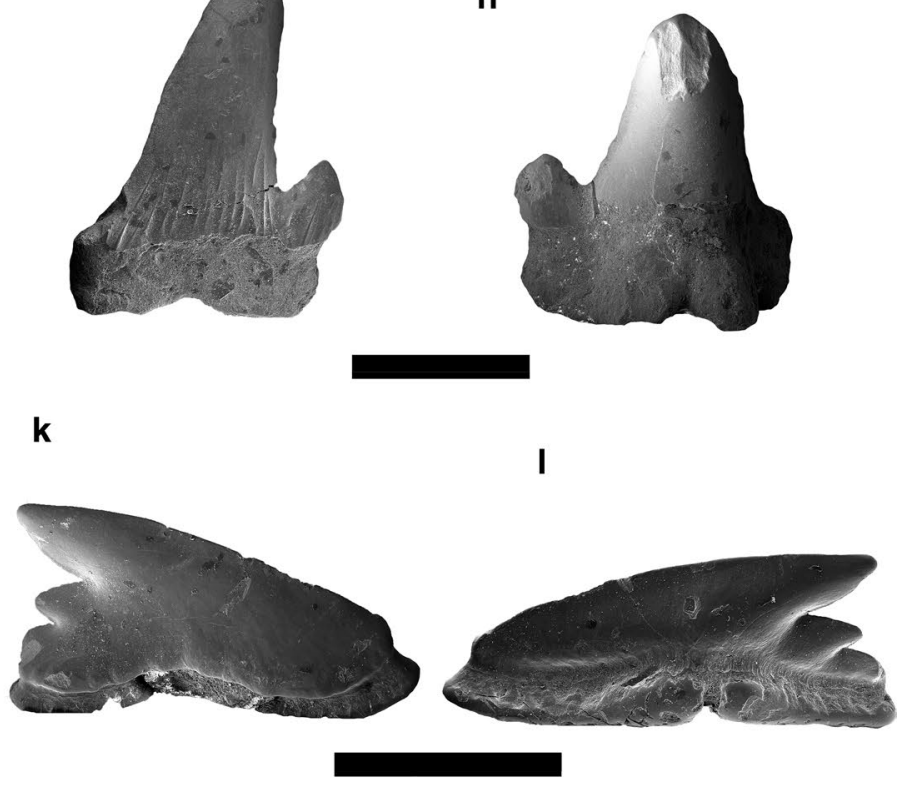

m

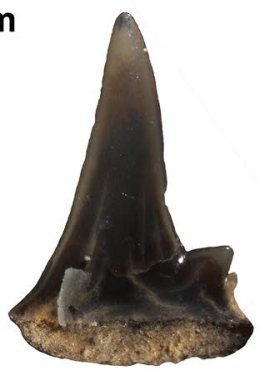

n

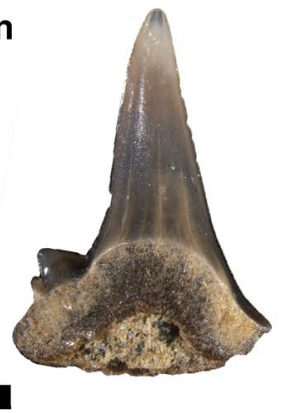

o

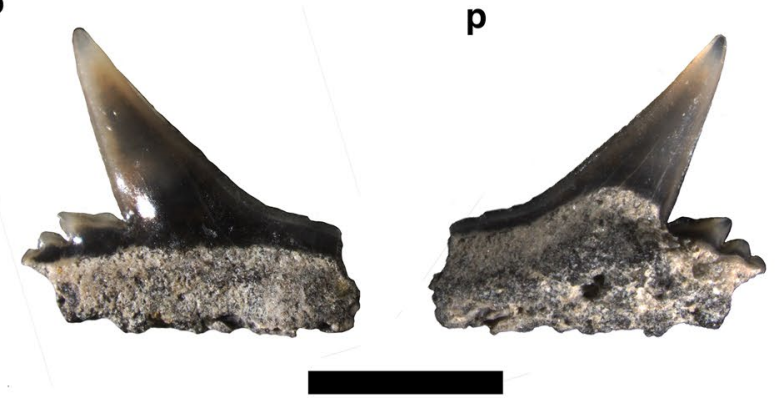

upper lateral tooth, $\mathbf{m}-\mathbf{p}$ Paragaleus pulchellus. Labial: a, $\mathbf{c}, \mathbf{e}, \mathbf{g}, \mathbf{i}, \mathbf{k}$, $\mathbf{m}, \mathbf{p}$; lingual: b, d, f, h, j, l, n, o. Scale bar $1 \mathrm{~mm}$
Fig. 7 Carcharhiniformes. a-d Scyliorhinus fossilis, a, b anterior tooth, c, d lateral tooth, e, f Scyliorhinus sp., $\mathbf{g}-\mathbf{j}$ Pachyscyllium distans, $\mathbf{g}, \mathbf{h}$ anterior tooth, $\mathbf{i}, \mathbf{j}$ lateral tooth, $\mathbf{k}, \mathbf{l}$ Chaenogaleus affinis,

The species S. joleaudi described by Cappetta (1970) from the Miocene of southern France represents a junior synonym of $S$. fossilis. Reinecke et al. (2011) reported the presence of $S$. fossilis (aka $S$. joleaudi) from the early
Miocene of northern Germany. The teeth described here display a typical morphotype of $S$. fossilis with mesio-distally expanded crown base and several, very strong vertical folds and lateral cusplets. 


\section{Scyliorhinus sp.}

Figure 7e, f

Material. Seven lateral teeth-SNSB-BSPG 2019 III-72, SNSB-BSPG 2019 III-73 (six teeth).

Description. The teeth of this catshark are abraded and incompletely preserved (Fig. 7e, f). The main cusp is triangular in labial view, slightly bent distally, and lingually curved. Basally, short vertical folds are present on the lingual crown face, whereas the lingual face is smooth. The preserved cusplets are high, triangular and straight without any ornamentation. The cutting edges are completely smooth. The cusp is separated from the lateral cusplets by a deep notch. The root is heavily abraded; thus, the lingual protuberance is missing.

Remarks. Scyliorhinus is a diverse genus comprising 16 extant species (Froese and Pauly 2019). They are globally distributed in tropical to arctic waters, from the intertidal to the deep-sea zones (Compagno 1984b). In the Mediterranean Sea the lesser spotted dogfish (S. canicula), the Dumahel's catshark ( $S$. duhamelii) and the nursehound $(S$. stellaris) have been reported (Soares et al. 2019). The fossil record of Scyliorhinus extends back to the lower Cretaceous (Cappetta 2012). Early Miocene records were reported from Austria (Schultz 2013), Germany (Barthelt et al. 1991; Reinecke et al. 2011), Switzerland (Leriche 1927) and the USA (Case 1980).

The material described here can be unambiguously identified as Scyliorhinus based on the typical characters of this genus (i.e. sharp and rather slender cusp with one pair of lateral cusplets). However, due to the very abraded condition of the teeth and their incompleteness it is not possible to assign these teeth to any species known to date.

Genus Premontreia Cappetta, 1992

Type species. Premontreia degremonti Cappetta, 1992

Premontreia distans (Probst, 1879)

Figure $7 \mathrm{~g}-\mathrm{j}$

Material. Five anterior teeth-SNSB-BSPG 2019 III-74, SNSB-BSPG 2019 III-75 (4 teeth); and 14 lateral teethSNSB-BSPG 2019 III-76, SNSB-BSPG 2019 III-77 (13 teeth).

Description. In the anterior teeth (Fig. $7 \mathrm{~g}, \mathrm{~h}$ ), the main cusp is triangular and rather low in lingual view with one pair of lateral cusplets. The main cusp and the lateral cusplets are lingually curved. The lateral cusplets are broad and triangular. In labial view, vertical folds are present at the base of the crown. The lingual cusp face is smooth, but faint folds are developed on the lateral cusplets. The root is high in lingual view with a lingual protuberance and shallow nutritive groove. The root lobes below the lateral cusplets seem to have been very narrow as far as can be ascertained.

The lateral teeth (Fig. 7i, j) display an incomplete triangular, broad and distally inclined cusp. The lateral cusplets also are triangular and very broad. Some folds are present at the base of the lateral cusplets on both faces. The labial face of the crown overhangs the root. The crown/root boundary is concave medially and rounded at the distal and mesial regions. The root is slightly broader than the crown and is heart-shaped in basal view.

Remarks. Premontreia distans is very common in the Oligocene and Miocene of the North Sea basin and adjacent regions (Antunes et al. 1981; Lienau 1987; Haye et al. 2008; Reinecke et al. 2008). This taxon was originally allocated to Scyliorhinus (Joleaud 1912). However, Cappetta (2006) and Reinecke et al. (2008) placed this species into the extinct scyliorhinid taxon Premontreia. Early Miocene records were reported from France (Cappetta 1970, 1973, as Scyliorhinus distans), Germany (Probst 1879, as Scyllium distans; von Ihering 1927; Barthelt et al. 1991, as Scyliorhinus distans; Sachs 2016), Portugal (Antunes et al. 1981, as Scyliorhinus distans), Switzerland (Bolliger et al. 1995, as Scyliorhinus distans; Jost et al. 2016) and the USA (Case 1980). We followed the opinion of Reinecke et al (2011), considering $P$. distans as valid species based on its diagnostic characters (i.e. labial ridges at the base of the crown and the convex curvature of the mesial cutting edge). Therefore, the material described here can be unambiguously identified at species level based on the presence of those characters.

Family Hemigaleidae Hasse, 1879

Genus Chaenogaleus Gill, 1862

Type species. Chaenogaleus macrostoma (Bleeker, 1852)

Chaenogaleus affinis (Probst, 1879)

Figure $7 \mathrm{k}, 1$

Material. 13 upper antero-lateral teeth-SNSB-BSPG 2019 III-78, SNSB-BSPG 2019 III-79 (2 teeth), SNSB-BSPG 2019 III-80 (10 teeth).

Description. The teeth show a high, broad and distally inclined cusp (Fig. 7k, 1). The mesial cutting edge is convex or slightly sigmoidal in some teeth, whereas the distal cutting edges are straight or convex. The distal heel shows two to four serrations decreasing in size towards the rear. The enameloid surface displays weak folds at the base of the 
lingual and labial faces. The root is low and slightly wider than the crown. It shows a well-marked lingual protuberance, which is divided by a nutritive groove.

Remarks. The fossil species $C$. affinis ranges from the early Miocene to late Miocene (Cappetta 2012). Early Miocene records were reported from Austria (Schultz 2013), France (Cappetta 1970, as Galeorhinus affinis), Germany (Probst 1878, as Galeus affinis; von Ihering 1927; Barthelt et al. 1991; Reinecke et al. 2011; Pollerspöck and Beaury 2014; Sach 2016), Switzerland (Fischli 1930, as Galeus affinis; Bolliger et al. 1995; Jost et al. 2016) and the USA (Case 1980, Galeorhinus affinis). According to Herman et al. (2001), the teeth of the only extant species C. macrostoma have more elongated and slender cusps in upper anterolateral than the fossil representative $C$. affinis. The teeth reported here also bear dental characters observed in the material from early Miocene of Northern Germany and middle Miocene of Czech Republic (Schultz et al. 2010; Reinecke et al. 2011).

Genus Paragaleus Budker, 1935

Type species. Paragaleus gruveli Budker, 1935

Paragaleus pulchellus (Jonet, 1966)

Figure $7 \mathrm{~m}-\mathrm{p}$

Material. One lower anterior-SNSB-BSPG 2019 III-81; and 30 lower lateral teeth-SNSB-BSPG 2019 III-82, SNSB-BSPG 2019 III-83 (19 teeth).

Description. The lower anterior tooth has a slender and erect cusp (Fig. $7 \mathrm{~m}, \mathrm{n}$ ). The mesial cutting edge is concave at its base and straight at its upper part. The distal heel is short with two sharp cusplets, which are distally inclined. The enameloid surface is completely smooth. The root is incomplete; however, the lingual protuberance is well preserved.

The lower lateral tooth has a long, slender and strongly distally inclined cusp (Fig. 7o, p). The mesial cutting edge is concave, whereas the distal one is slightly convex. The distal heel is short and features three acute and distally oriented cusplets. The root is incomplete mesially and distally. The lingual protuberance is abraded, but nonetheless preserves a medial foramen.

Remarks. The fossil record of $P$. pulchellus ranges from the early to late Miocene (Cappetta 2012). Reinecke et al. (2011) also indicated the possible presence of $P$. pulchellus in the early Miocene of northern Germany. The taxonomic assignment of $P$. pulchellus has been debated for many years. Jonet (1966) erected Galeorhinus pulchellus based on the teeth from the late Miocene of Portugal. Later, Cappetta (1970) included this species within the genus Paragaleus. Additionally, Barthelt et al. (1991) considered Galeorhinus tenuis as synonym of $P$. pulchellus, a view we follow in the present study. Early Miocene records of $P$. pulchellus were reported from Austria (Schultz 2013), France (Cappetta 1970), Germany (Reinecke et al. 2011), Portugal (Antunes et al. 1981) and Venezuela (Aguilera and de Aguilera 2004).

Based on the high similarities between our teeth and those from the early Miocene of northern Germany, we identify the teeth described here as belonging to the species P. pulchellus.

Superorder Batomorphii Cappetta, 1980

Order Myliobatiformes Compagno, 1973

Family Aetobatidae Agassiz, 1858

Genus Aetobatus de Blainville, 1816

Type species. Raja aquila Linnaeus, 1758

Aetobatus sp.

Figure 8a, b

Material. Six lower symphysial teeth-SNSB-BSPG 2019 III-84, SNSB-BSPG 2019 III-85, SNSB-BSPG 2019 III-86 (four teeth).

Description. The symphyseal teeth are transversely elongated and V-shaped in occlusal view (Fig. 8a, b). The lateral edges of the symphyseal teeth form an obtuse angle. The teeth are labio-lingually thicker in the central region than in the lateral region. The crown surface is very abraded in all the examined teeth. The root vascularization is of the polyaulacorhizous type, with laminae and shallow nutritive grooves.

Remarks. Aetobatus is currently represented by five species: A. flagellum, A. laticeps, A. narinari, A. narutobiei and A. oceallatus, living in tropical and warm-temperate seas (Last et al. 2016). This genus is absent in the Mediterranean Sea. Its fossil record extends back to the upper Paleocene (Cappetta 2012). Early Miocene records were reported from Austria (Schultz 2013), Egypt (Cook et al. 2010), France (Cappetta 1970, 1973; Goedert et al. 2017), Germany (Barthelt et al. 1991; Baier et al. 2004; Reinecke et al. 2011; Sach 2016), Panamá (Gillette 1984), Portugal (Zbyszewski 1949), Slovakia (Holect et al. 1995), Switzerland (Leriche 1927; Bolliger et al. 1995) and the USA (Purdy 1998).

Our material displays the typical shape of Aetobatus teeth, i.e. V-shaped symphyseal teeth without any lateral teeth. Although Reinecke et al. (2011) described A. arcuatus from the early Miocene of northern Germany, its diagnostic characters are not very clear. According 

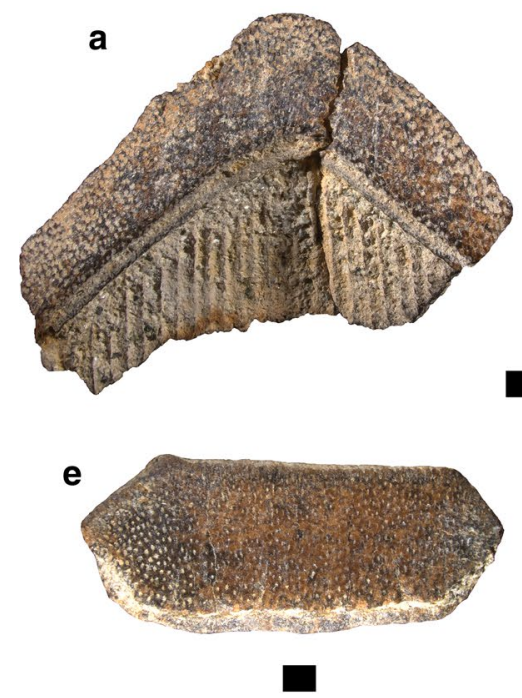

i

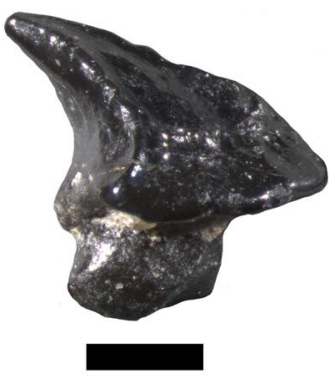

m

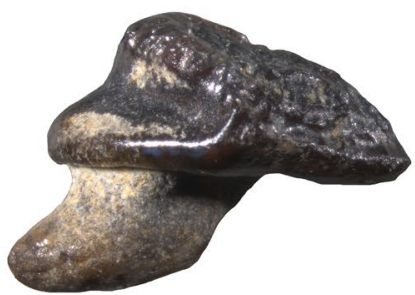

q
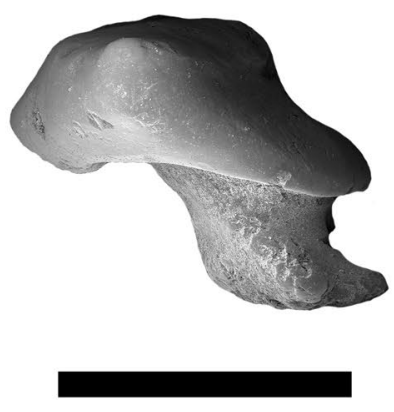

C

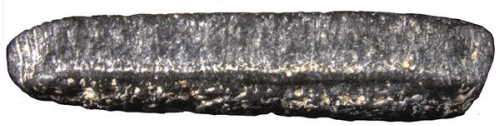

d

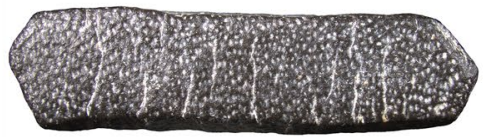

g
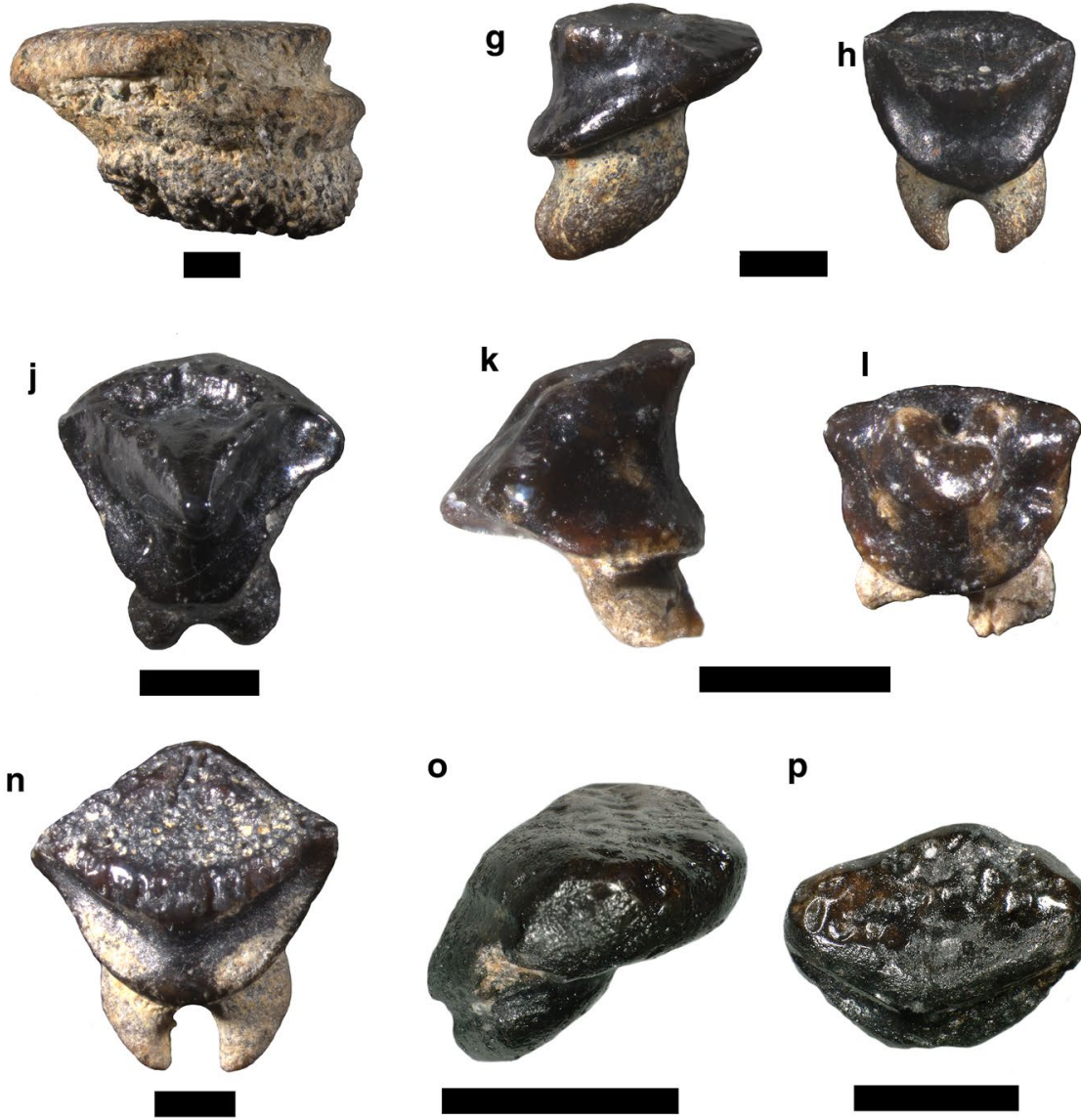

o
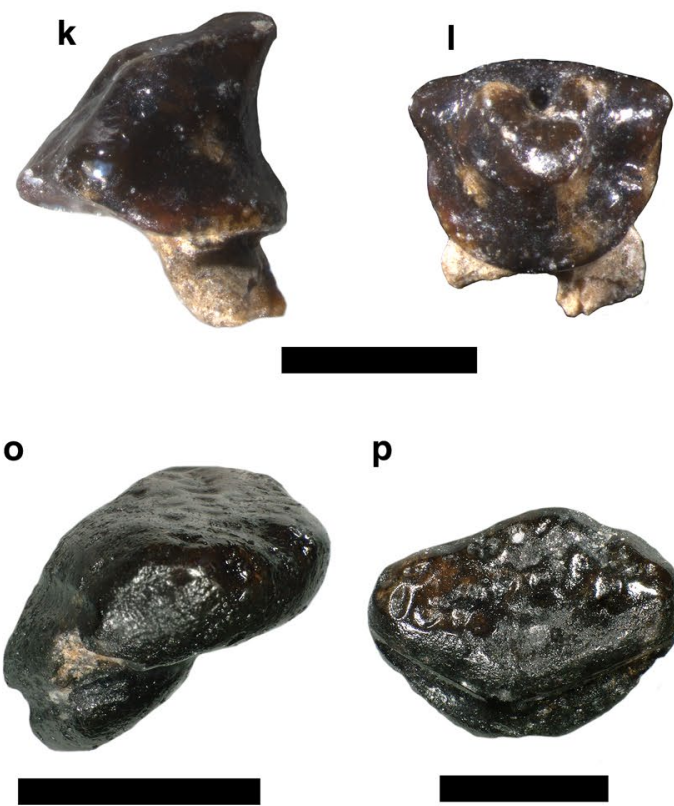

$\mathbf{p}$
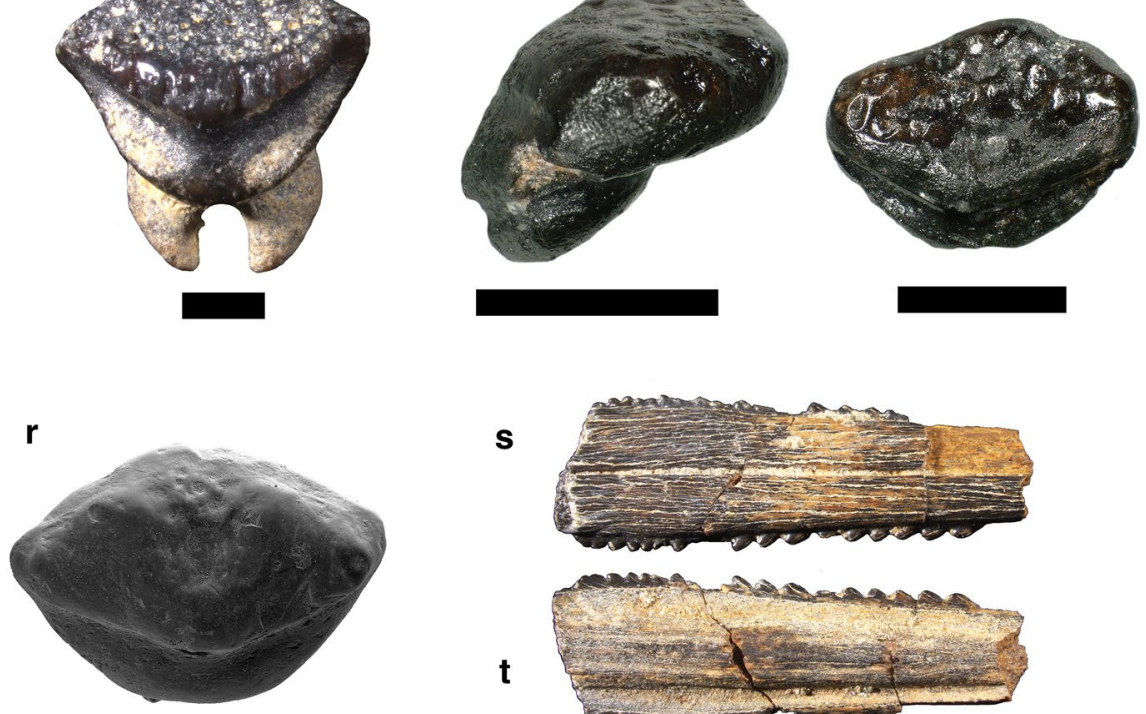

$\mathbf{s}$

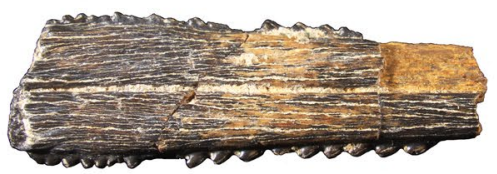

$\mathbf{t}$

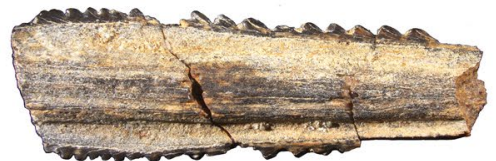

(1)

Fig. 8 Myliobatiformes a, b Aetobatus sp., c, d Myliobatis sp., e, f $\quad$ Myliobatiformes indet. Basal: b; dorsal: s; lingual: c, h, j, l, n; oclusRhinoptera sp., g-j Taeniurops cavernosus, $\mathbf{k}, \mathbf{l}$ Dasyatis probsti, $\mathbf{m}, \quad$ sal: a, d, e, p, r; profile: f, $\mathbf{g}, \mathbf{i}, \mathbf{k}, \mathbf{m}, \mathbf{o}$, q; dorsal: $\mathbf{s}$; ventral: t. Scale n Dasyatis rugosa, $\mathbf{o}, \mathbf{p}$ Dasyatis strangulata, $\mathbf{q}, \mathbf{r}$ Dasyatis sp., $\mathbf{s}, \mathbf{t}$ bar $1 \mathrm{~mm}$ 
to Hovestadt and Hovestadt-Euler (2013), identification at the species level of isolated teeth only is not possible due the high intraspecific variability of dental characters. Therefore, we abstain from assigning these teeth to any species.

Family Myliobatidae Bonaparte, 1838

Genus Myliobatis Cuvier, 1817

Type species. Raja aquila Linnaeus, 1758

Myliobatis sp.

Figure 8c, d

Material. Ten symphyseal teeth-SNSB-BSPG 2019 III-87, SNSB-BSPG 2019 III-88, SNSB-BSPG 2019 III-89 (eight teeth).

Description. The symphyseal teeth are very abraded and some of them are broken (Fig. 8c, d). The crown is transversely elongated with straight labial and lingual margins in occlusal view. The teeth are four to five times wider than long. All specimens have a hexagonal outline. The occlusal surface of the symphyseal teeth is smooth. The root is abraded, but it displays the typical polyaulacorhizous vascularization type.

Remarks. The genus Myliobatis is currently represented by 11 globally distributed species occurring in temperate and tropical seas (Last et al. 2016). The common eagle ray ( $M$. aquila) is the only species recorded from the Mediterranean Sea (McEachran and Séret 1990). Reliable fossils of Myliobatis extend back to the Late Cretaceous (Claeson et al. 2010; Cappetta 2012). Early Miocene records were reported from Austria (Schultz 2013), Chile (Suarez et al. 2006), France (Cappetta 1970), Germany (Barthelt et al. 1991; Scholz and Bienert 1992; Baier et al. 2004; Reinecke et al. 2011; Pollerspöck and Beaury 2014; Sach 2016), Hungary (Kordos and Solt 1984), Panamá (Gillette 1984), Portugal (Antunes et al. 1981), Spain (Vicens and Rodríguez-Perea 2003), Switzerland (Leriche 1927; Bolliger et al. 1995), the the USA (Case 1980) and Venezuela (Aguilera and de Aguilera 2004). As in Aetobatus, taxonomic identification of extinct Myliobatis species only based on isolated teeth is extremely difficult due the high dental variation within the genus (Hovestadt and Hovestadt-Euler 2013).

Family Rhinopteridae Jordan and Evermann, 1896

Genus Rhinoptera Cuvier, 1829
Type species. Myliobatis marginata Geoffroy Saint Hilaire, 1817

Rhinoptera sp.

Figure 8e, $\mathrm{f}$

Material. Four symphyseal teeth-SNSB-BSPG 2019 III90, SNSB-BSPG 2019 III-91 (three teeth); and three lateral teeth-SNSB-BSPG 2019 III-92, SNSB-BSPG 2019 III-93 (two teeth).

Description. The symphyseal teeth are broader than long with a hexagonal contour (Fig. 8e, f). In occlusal view, the teeth are straight or slightly arched lingually. The crown surface is smooth. The root shows a polyaulacorhizid vascularization type with numerous parallel laminae and nutritive grooves. The most complete specimen has 12 laminae in basal view. In profile view, the root is slightly displaced lingually and lingually separated from the crown by a bulge. The lateral tooth has a regular hexagonal outline, being less transversely enlarged than the symphyseal teeth. The crown surface is completely smooth.

Remarks. The genus Rhinoptera is currently known by eight species distributed in temperate and tropical oceans (Last et al. 2016). The Lusitanian crownose ray (R. marginata) is the only species reported from the Mediterranean Sea (McEachran and Séret 1990). The fossil record of Rhinoptera extends back into the upper Palaeocene (Cappetta 2012). Early Miocene records are from Austria (Schultz 2013), Brazil (Távora et al. 2010), France (Cappetta 1970; Goedert et al. 2017), Germany (Lutzeier 1922; Barthelt et al. 1991; Baier et al. 2004; Sach 2016), India (Mondal et al. 2009), Panamá (Gillette 1984), Portugal (Zbyszewski 1949; Antunes et al. 1981), Switzerland (Leriche 1927; Fischli 1930; Bolliger et al. 1995), the USA (Case 1980) and Venezuela (Aguilera and de Aguilera 2004).

According to Herman et al. (2000) and Cappetta (2012), the symphyseal teeth of Rhinoptera are longer, but less broad transversely than Aetobatus and Myliobatis. Considering these dental characters, we can assign these teeth unambiguously to the genus Rhinoptera. However, due to the lack of diagnostic characters, identification at specific level remains difficult.

Family Dasyatidae Jordan, 1888

Genus Taeniurops Garman, 1913

Type species. Taeniura meyeni Müller and Henle, 1841 
Taeniurops cavernosus (Probst, 1877)

Figure $8 \mathrm{~g}-\mathrm{j}$

Material. 23 female teeth-SNSB-BSPG 2019 III-94, SNSB-BSPG 2019 III-95 (22 teeth); and ten male teethSNSB-BSPG 2019 III-96, SNSB-BSPG 2019 III-97 (8 teeth), SNSB-BSPG 2019 III-98.

Description. The female teeth have a rather high and acute crown, which is lingually inclined in profile view (Fig. 8g, h). The crown shows a labial and lingual visor divided by a sharp transverse crest. This crest displays some folds along the distal and mesial edges. The lower region of the labial visor is slightly convex and exhibits a reticulate ornamentation whereas the upper region is concave and smooth. The lingual visor is concave in profile view with a smooth surface. The root is high with two separated lobes.

Male teeth display a strong cuspidate and lingually oriented cusp (Fig. 8i, j). The labial visor is long with a slightly convex and ornamented lower region whereas the upper region is depressed and smooth. The transversal crest also is folded in its distal and mesial edges. The root is rather low and directed lingually with two short lobes.

Remarks. The fossil record of T. cavernosus ranges from the lower to the middle Miocene (Reinecke et al. 2011; Cappetta 2012). Early Miocene records were only reported from Germany (Probst 1877, as Raja cavernosa; Barthelt et al. 1991, as Dasyatis cavernosa; Reinecke et al. 2011; Sach 2016), Portugal (Antunes et al. 1981, as Dasyatis cavernosa), Switzerland (Fischli 1930, as Trygon cavernosus; Bolliger et al. 1995) and the USA (Case 1980). According to Cappetta (2013), the genus Taeniurops has been confused very often with Dasyatis. However, Taeniurops shows a distinctively depression in the labial visor which is borderer by a sharp crest, thus differing from the condition seen in Dasyatis. Male and female teeth reported here resemble the material described from the early Miocene of northern Germany (Reinecke et al. 2011).

Genus Dasyatis Rafinesque, 1810

Type species. Dasyatis ujo Rafinesque, 1810

Dasyatis probsti Cappetta, 1970

Figure 8k, 1

Material. Twelve male teeth-SNSB-BSPG 2019 III-99, SNSB-BSPG 2019 III-100 (11 teeth).

Description. The teeth have a cuspidate crown, which is lingually inclined (Fig. 8k, 1). The labial visor is smooth and slightly convex; however, its medial region is deeply depressed. The lingual visor is also smooth and concave in profile view. The transversal crest is faintly folded. The labial margin is convex and weakly ornamented. The root is rather high and lingually oriented with two well-separated lobes.

Remarks. Dasyatis probsti ranges from the early to the middle Miocene (Reinecke et al. 2011). Early Miocene records were reported from France (Cappetta 1970, 1973), Germany (Reinecke et al. 2011; Pollerspöck and Beaury 2014) and Switzerland (Bolliger et al. 1995). Dasyatis probsti can be distinguished from $T$. cavernosus and D. rugosa by its deep depression on the labial visor and the weakly ornamented labial margin of the crown.

\section{Dasyatis rugosa Probst, 1877}

Figure 8m, n

Material. 33 female teeth-SNSB-BSPG 2019 III-101, SNSB-BSPG 2019 III-102 (29 teeth), SNSB-BSPG 2019 III-103 (3 teeth).

Description. The teeth show a rather low and lingually oriented crown (Fig. 8m, n). The labial visor is convex in profile view and strongly ornamented. The lingual visor is concave in profile view with a smooth surface. In occlusal view, the labial visor is angular. The root is rather high and directed lingually with two massive lobes.

Remarks. The fossil record of D. rugosa ranges from the Oligocene to the middle Miocene (Reinecke et al. 2011). Early Miocene records were reported from Austria (Schultz 1998), France (Cappetta 1970, 1973), Germany (Probst 1877, as Raja rugosa; Barthelt et al. 1991; Reinecke et al. 2011; Pollerspöck and Beaury 2014; Sach 2016), Portugal (Antunes et al. 1981), Switzerland (Bolliger et al. 1995; Jost et al. 2016) and the USA (Kent 2018).

The material described here shows the diagnostic characters of teeth of D. rugosa, i.e. a strongly ornamented labial visor and a labial visor that appears as angular in occlusal view. These dental characters were also observed in teeth from the early Miocene of northern Germany (Reinecke et al. 2011).

Dasyatis strangulata (Probst, 1877)

Figure 8o, p

Material. Two female teeth-SNSB-BSPG 2019 III-104, SNSB-BSPG 2019 III-105.

Description. The female teeth show a bulging and lingually directed crown (Fig. 8o, p). The transverse ridge is roughly 
pronounced, separating the labial and lingual visors. The labial visor is almost flat with a weakly reticulated surface, whereas the lingual visor is short, smooth and slightly convex in profile view. The labial margin of the crown is very thick and convex. The root is very low with two short lobes.

Remarks. Teeth of D. strangulata are very rare in the fossil record. This species ranges from the early Miocene to the Pliocene. Early Miocene records were only reported from Germany (Probst 1877, as Raja strangulata; Reinecke et al. 2011). D. strangulata can be distinguished from other species of Dasyatis and Taeniurops by the bulging crown shape and the absence of a labial depression.

\section{Dasyatis sp.}

Figure 8q, r

Material. One female tooth-SNSB-BSPG 2019 III-106.

Description. The single tooth displays a rather bulging and lingually oriented cusp (Fig. 8q, r). The labial visor is weakly reticulated, whereas the lingual visor is completely smooth. In profile view, the labial visor is strongly convex and the lingual visor is concave in its medial region. In occlusal view, the crown displays a semicircular outline. The root is low with two short well-separated lobes.

Remarks. According to Last et al. (2016), Dasyatis is currently represented by five species with a global distribution. Of these, three (i.e. the marbled stingray D. marmorata, the common stingray $D$. pastinaca and the Tortonese's stingray D. tortonesi) are currently present in the Mediterranean Sea (Cowley and Compagno 1993). The fossil record of Dasyatis extends back into the early Cretaceous, although most of the species might belong to different genera (Underwood et al 1999; Cappetta 2012). Early Miocene records were reported from Austria (Schultz 2013), France (Cappetta 1970), Germany (Barthelt et al. 1991; Reinecke et al. 2011), the USA (Purdy 1998) and Venezuela (Aguilera and de Aguilera 2004).

\section{Myliobatiformes indet.}

Figure $8 \mathrm{~s}, \mathrm{t}$

Material. Six incomplete tail spines-SNSB-BSPG 2019 III-107, SNSB-BSPG 2019 III-108 (three incomplete tail spines), SNSB-BSPG 2019 III-109 (two incomplete tail spines).

Description. The six tail spines are incomplete, missing their distal and proximal portions (Fig. 8s, t). They are dorsoventrally flattened, narrow and elongated. In dorsal view, an antero-posteriorly directed central groove and additional irregularly shaped grooves are observed. In ventral view, a central ridge is present, but weakly pronounced. Both sides of the tail spines display flat denticles that project latero-proximally.

Remarks. Living stingrays (Myliobatiformes) are represented by ten families (Last et al. 2016). Early Miocene records of tail spines were reported from northern Germany (Reinecke et al. 2011), Venezuela (Carrillo-Briceño et al. 2016b) and Peru (Bianucci et al. 2018; Landini et al. 2019).

According to the recent review by Hovestadt and Hovestadt-Euler (2013), in general, there are no unambiguous characters that might be useful to distinguish tail spines at genus or family level. Moreover, their morphology could also vary ontogenetically. Therefore, we prefer to keep their identification to a higher taxonomic level.

Order Rajiformes Berg, 1937

Family Rajidae de Blainville, 1816

Genus Raja Linnaeus, 1758

Type species. Raja miraletus Linnaeus, 1758

\section{Raja sp.}

Figure 9a, d

Material. 17 female teeth-SNSB-BSPG 2019 III-110, SNSB-BSPG 2019 III-111 (10 teeth), SNSB-BSPG 2019 III-112 (six teeth); and 15 male teeth-SNSB-BSPG 2019 III-113, SNSB-BSPG 2019 III-114 (13 teeth), SNSB-BSPG 2019 III-115.

Description. Most of the teeth are very abraded and in some of them the apex is missing. The male teeth display a very high and cuspidate crown, which is lingually oriented (Fig. 9a, b). The enameloid surface is completely smooth on both the labial and lingual faces. The cutting edges are smooth along the mesial and distal edges of the cusp, and they do not reach the base of the cusp. The base of the crown displays a rounded rim with an oval shape in occlusal view. The root is low and mesio-distally expanded with two short but wide lobes. The median furrow is narrow and shallow.

The female teeth display a rounded and low crown, which is lingually oriented (Fig. 9c, d). The cutting edges are mostly smooth. They do not reach the basal rim of the crown. Some teeth display some ridges on the transverse crest in the distal and mesial edges. In profile view, the labial crown face is strongly convex whereas the lingual face is slightly convex. The root is low with two wide and short lobes.

Remarks. The genus Raja is currently represented by 16 globally distributed species (Last et al. 2016). In the 

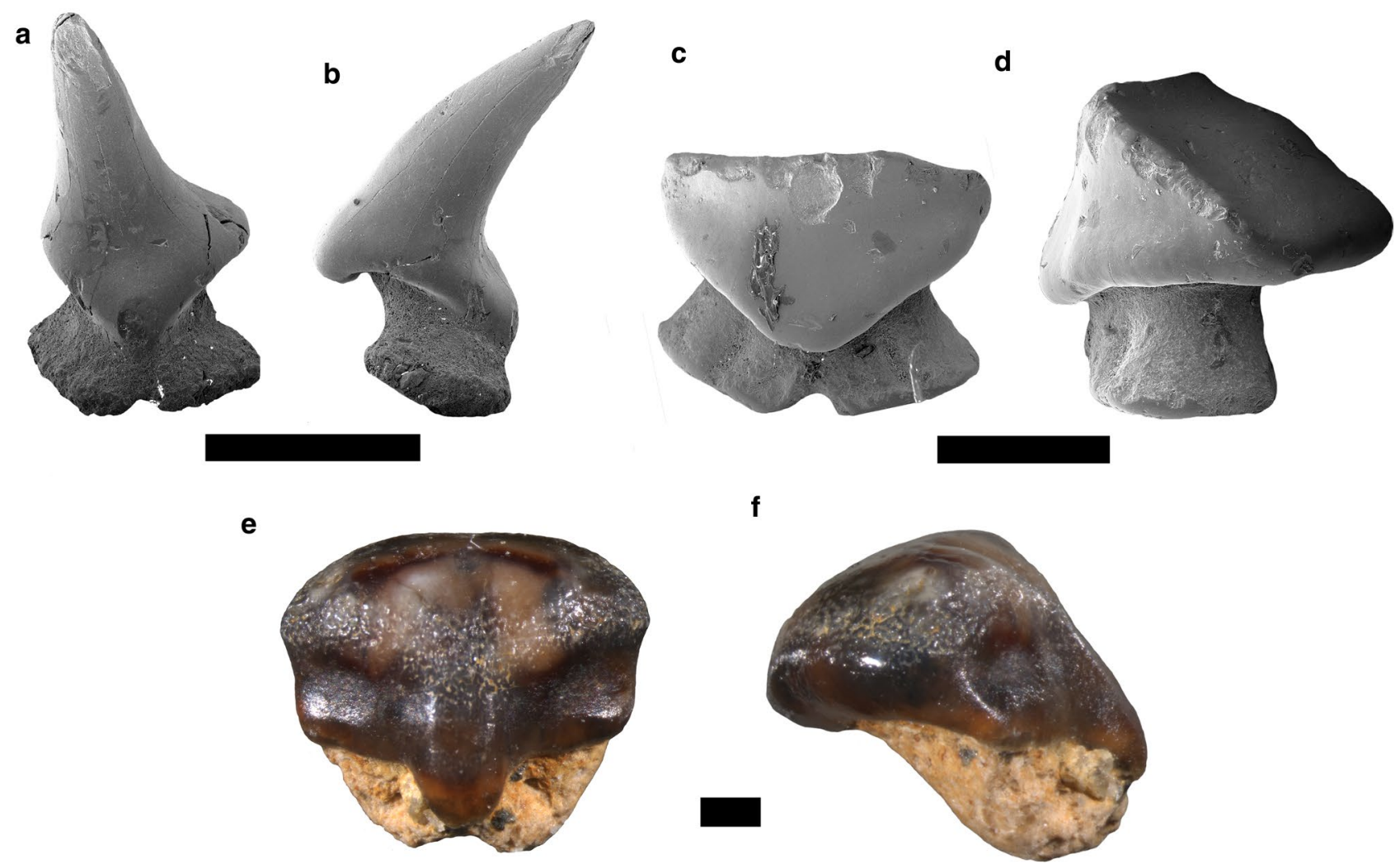

Fig. 9 Rajiformes. a-d Raja sp., a, b male tooth, c, d female tooth, Rhinopristiformes, e, f Rhynchobatus sp. Lingual: a, c, e; profile: b, d, f. Scale bar $0.5 \mathrm{~mm}$

Mediterranean Sea, nine species have been reported (e.g. $R$. asterias and $R$. clavata) up to now (Serena 2005). The fossil record of Raja extends back into the upper Cretaceous, although most of the geologically oldest species probably do not belong to the living genus (Cappetta 2012). Early Miocene records were reported from Austria (Schultz 2013), France (Cappetta 1970, 1973), Germany (Barthelt et al. 1991; Reinecke et al. 2011; Pollerspöck and Beaury 2014), Hungary (Kordos and Solt 1984), India (Sahni and Mehrotra 1981), Portugal (Antunes et al. 1981), Switzerland (Fischli 1930; Bolliger et al. 1995) and the USA (Purdy 1998; Kent 2018). Reinecke et al. (2011) described the species Raja cecilae and Raja holsatica from the early Miocene of northern Germany. However, their diagnostic characters were not described in detail. Although our material shows the general morphology of Raja, these dental characters are different from those described from Germany. Due to the poor preservation state, we prefer to identify them at the genus-level.

Order Rhinopristiformes Naylor et al., 2012

Family Rhinidae Müller and Henle, 1841

Genus Rhynchobatus Müller and Henle, 1837
Type species. Rhinobatus laevis (Bloch and Schneider, 1801)

\section{Rhynchobatus sp.}

Figure 9e, f

Material. Five teeth-SNSB-BSPG 2019 III-116, SNSBBSPG 2019 III-117 (four teeth).

Description. The teeth have a globular crown, which is wider than long (Fig. 9e, f). The crown is divided into three regions: labial, central and lingual faces. In profile view, the labial crown face is strongly convex. The central crown face is slightly depressed and weakly separated from the labial face by a transverse crest. The lingual face is oblique and slightly depressed. The crown surface is ornamented by granules around the labial and lingual faces not reaching the basal margins. The lingual uvula is wide and quite short. The root is very short, oriented lingually and divided by two lobes.

Remarks. The genus Rhynchobatus is currently represented by eight species that inhabit the Indian, western Pacific and eastern Atlantic oceans, being in turn absent in the Mediterranean Sea (Last et al. 2016). The fossil record of 
Rhynchobatus extends back into the lower Eocene (Cappetta 2012). Early Miocene records were reported from France (Cappetta 1970, 1973), Germany (Barthelt et al. 1991; Reinecke et al. 2011; Sach 2016), Malta (Ward and Bonavia 2001), Portugal (Antunes et al. 1981), Switzerland (Bolliger et al. 1995), the USA (Case 1980; Kent 2018) and Venezuela (Aguilera and de Aguilera 2004).

The teeth described herein display the typical characters of the genus Rhynchobatus, i.e. the oral face is divided into three regions, the enameloid is granular and the uvula is wide. A number of species of Rhynchobatus and R. pristinus have been reported from the early Miocene of Germany (Barthelt et al. 1991; Schultz 2013). However, the diagnostic characters of this species are not clear, thus, we prefer to identify it at generic level until more material is available.

\section{Discussion}

\section{Taxonomic composition of Simssee fauna}

Elasmobranch remains are quite common in the Marine Molasse Basin of southern Germany and highlight a diversified cartilaginous fish fauna (Barthelt et al. 1991; Pollerspöck and Straube 2017; this study). Sharks, rays and skates are well represented in the fossiliferous deposits of the Achen Formation in the Simssee area. However, most of the remains are too incomplete or abraded to allow an unambiguous identification at the species level (e.g. Myliobatis and Scyliorhinus). The elasmobranch fauna from the early Miocene of Simssee/Bavaria is represented by 37 taxa (Figs. 2, 3, 4, 5, 6, 7, 8, and 9), including 26 sharks (70\%, 26 out of 37 species) and 11 batoids (30\%, 11 out of 37) (Table 1). The asymptotic trend of the rarefaction curve (Fig. 10) suggests that the taxonomic inventory is largely complete. In addition, the Chao 1 non-parametric estimator suggests that the completeness of the inventory would be no less than 89\% (Fig. 10): indeed, the upper level confidence interval (95\%) of the Chao 1 extrapolation index suggests that the total inventory would be ca. 41 taxa, i.e. 4 taxa more than those that have been observed. The sharks are mainly represented by members of the orders Carcharhiniformes (46\%, 12 out of 26 shark species) and Lamniformes (23\%, 6 of 26), whereas for batoids, the order Myliobatiformes is the most dominant group ( $82 \%, 9$ of 11$)$. At the family level, the carcharhinids and the dasyatids are the most diverse groups of sharks and batoids, respectively. At lower taxonomic levels, 31 genera and 20 species of early Miocene elasmobranchs were described. All the taxa described herein were previously reported from other early Miocene localities of Germany (e.g. Barthelt et al. 1991; Reinecke et al. 2011;
Pollerspöck and Straube 2017). Significantly, we provided the first records of the shark species Paragaleus pulchellus and Physogaleus contortus from southern Germany. Additionally, we confirmed the presence of the rare species Dasyatis strangulata from Germany.

\section{Ecological traits of the identified taxa}

Identifiable cartilaginous fishes from the Simssee area comprise taxa that are common elements in marine sediments of Miocene age throughout Europe (Cappetta 1970, 1973; Antunes et al. 1981; Kocsis 2007; Marsili et al. 2007; Reinecke et al. 2011; Schultz 2013). All the reported taxa are nektonic or nektobenthic organisms and some of them are able to migrate over long distances (e.g. Alopias, Carcharhinus and Squalus) (McFarlane and King 2003; Cartamil et al. 2010; Conrath and Musick 2010). Most of the elasmobranchs reported here are inhabitants of shallow, nearshore and littoral marine waters in warm climatic zones, according to our current knowledge about their fossil distribution, and in comparison, with modern representatives (e.g. Aetobatus and Chaenogaleus) (Last et al. 2016; Froese and Pauly 2019). This is consistent with the current distribution of cartilaginous species in the Mediterranean Sea, which are mostly distributed on the continental shelf (Froese and Pauly 2019; Ramírez-Amaro et al. 2020). However, purported deep-water sharks are also present in the Simssee area (i.e. Chlamydoselachus, Centrophorus, Deania, Isistius, and Mitsukurina). Nowadays, only few deep-water sharks can be found below $1000 \mathrm{~m}$ in the Mediterranean Sea (e.g. Centrophorus granulosus and Hexanchus griseus) (Sion et al. 2004). Therefore, the presence of fossil and their extant representatives indicates that the sediments of the Simssee area were deposited in shallow-to-deep shelf environments. According to Kroh (2007), the echinoderm fauna from the early Miocene of the Central Paratethys inhabited shallow and deep-water environments. The co-presence of elasmobranchs inhabiting shallow and deep environments was also reported from other lower Miocene, Pliocene and Pleistocene European localities (Kocsis 2007; Marsili 2007; Fulgosi et al. 2009; Reinecke et al. 2011; Pollerspöck and Straube 2017).

\section{Paleobiogeographic dynamics}

The elasmobranch fauna described here experienced paleobiogeographic changes from the early Miocene to the recent (Table 1). At genus level, $10 \%$ of the recognised genera (3 out of 31) are globally extinct (Araloselachus, Physogaleus and Premontreia). Comparing the presence of the survived genera in the Mediterranean Sea today, two biogeographic dynamics are observed. Fifty percent of the living genera (14 out of 28) are absent in the Mediterranean Sea (Aetobatus, 
Table 1 Global status and present-day distribution in the Mediterranean Sea of chondrichthyans from Simsee area

\begin{tabular}{|c|c|c|c|c|c|}
\hline Superorder & Order & Family & Taxa & Global status & $\begin{array}{l}\text { Present-day distribution in the Mediter- } \\
\text { ranean }\end{array}$ \\
\hline Batomorphii & Myliobatiformes & Aetobatidae & Aetobatus sp. & Living & Absent \\
\hline Squalomorphii & Lamniformes & Alopiidae & Alopias exigua & $\dagger$ & A. superciliosus, A. vulpinus \\
\hline Squalomorphii & Lamniformes & Odontaspididae & Araloselachus cuspidatus & $\dagger$ & Absent \\
\hline Squalomorphii & Carcharhiniformes & Carcharhinidae & Carcharhinus priscus & $\dagger$ & $\begin{array}{l}\text { C. altimus, C. brachyurus, C. brevipinna, } \\
\text { C. falciformis, C. limbatus, C. melanop- } \\
\text { terus, C. obscurus, C. plumbeus }\end{array}$ \\
\hline Squalomorphii & Carcharhiniformes & Carcharhinidae & Carcharhinus sp. & Living & $\begin{array}{l}\text { C. altimus, C. brachyurus, C. brevipinna, } \\
\text { C. falciformis, C. limbatus, C. melanop- } \\
\text { terus, C. obscurus, C. plumbeus }\end{array}$ \\
\hline Squalomorphii & Lamniformes & Odontaspididae & Carcharias acutissimus & $\dagger$ & C. taurus \\
\hline Squalomorphii & Squaliformes & Centrophoridae & Centrophorus granulosus & Living & C. granulosus, C. uyato \\
\hline Squalomorphii & Carcharhiniformes & Hemigaleidae & Chaenogaleus affinis & $\dagger$ & Absent \\
\hline Squalomorphii & Hexanchiformes & Chlamydoselachidae & Chlamydoselachus sp. & Living & Absent \\
\hline Squalomorphii & Lamniformes & Lamnidae & Carcharodon hastalis & $\dagger$ & Absent \\
\hline Batomorphii & Myliobatiformes & Dasyatidae & Dasyatis probsti & $\dagger$ & D. marmorata, D. pastinaca, D. tortonesi \\
\hline Batomorphii & Myliobatiformes & Dasyatidae & Dasyatis rugosa & $\dagger$ & D. marmorata, D. pastinaca, D. tortonesi \\
\hline Batomorphii & Myliobatiformes & Dasyatidae & Dasyatis sp. & Living & D. marmorata, D. pastinaca, D. tortonesi \\
\hline Batomorphii & Myliobatiformes & Dasyatidae & Dasyatis strangulata & $\dagger$ & D. marmorata, D. pastinaca, D. tortonesi \\
\hline Squalomorphii & Squaliformes & Centrophoridae & Deania sp. & Living & Absent \\
\hline Squalomorphii & Carcharhiniformes & Carcharhinidae & Galeocerdo aduncus & $\dagger$ & Absent \\
\hline Squalomorphii & Squaliformes & Dalatiidae & Isistius triangulus & $\dagger$ & Absent \\
\hline Squalomorphii & Carcharhiniformes & Carcharhinidae & Isogomphodon acuarius & $\dagger$ & Absent \\
\hline Squalomorphii & Lamniformes & Mitsukurinidae & Mitsukurina lineata & $\dagger$ & M. owstoni \\
\hline Batomorphii & Myliobatiformes & Myliobatidae & Myliobatis sp. & Living & M. aquila \\
\hline Squalomorphii & Hexanchiformes & Hexanchidae & Notorynchus primigenius & $\dagger$ & Absent \\
\hline Squalomorphii & Lamniformes & Odontaspididae & Odontaspis molassica & $\dagger$ & O. ferox \\
\hline Squalomorphii & Carcharhiniformes & Hemigaleidae & Paragaleus pulchellus & $\dagger$ & Absent \\
\hline Squalomorphii & Carcharhiniformes & Carcharhinidae & Physogaleus contortus & $\dagger$ & Absent \\
\hline Squalomorphii & Carcharhiniformes & Scyliorhinidae & Premontreia distans & $\dagger$ & Absent \\
\hline Squalomorphii & Pristiophoriformes & Pristiophoridae & Pristiophorus sp. & Living & Absent \\
\hline Batomorphii & Rajiformes & Rajidae & Raja sp. & Living & $\begin{array}{l}\text { R. africana, } R . \text { asterias, } R . \text { brachyura, } R \text {. } \\
\text { clavata, } R . \text { miraletus, } R . \text { montagui, } R . \\
\text { polystigma, } R \text {. radula, } R \text {. undulata }\end{array}$ \\
\hline Batomorphii & Myliobatiformes & Myliobatidae & Rhinoptera sp. & Living & R. marginata \\
\hline Squalomorphii & Carcharhiniformes & Carcharhinidae & Rhizoprionodon sp. & Living & Absent \\
\hline Batomorphii & Rhinopristiformes & Rhinidae & Rhynchobatus sp. & Living & Absent \\
\hline Squalomorphii & Carcharhiniformes & Scyliorhinidae & Scyliorhinus fossilis & $\dagger$ & S. canicula, S. duhamelii, S. stellaris \\
\hline Squalomorphii & Carcharhiniformes & Scyliorhinidae & Scyliorhinus sp. & Living & S. canicula, S. duhamelii, S. stellaris \\
\hline Squalomorphii & Carcharhiniformes & Sphyrnidae & Sphyrna sp. & Living & $\begin{array}{l}\text { S. lewini, S. mokarran, S. tudes, S. } \\
\text { zygaena }\end{array}$ \\
\hline Squalomorphii & Squaliformes & Squalidae & Squalus sp. & Living & S. acanthias \\
\hline Squalomorphii & Squatiniformes & Squatinidae & Squatina sp. & Living & S. aculeata \\
\hline Batomorphii & Myliobatiformes & Dasyatidae & Taeniurops cavernosus & $\dagger$ & Absent \\
\hline
\end{tabular}

Chaeonagelus, Chlamydoselachus, Carcharodon, Deania, Galeocerdo, Isitius, Isogomphodon, Notorynchus, Paragaleus, Pristiophorus, Rhizoprionodon, Rhynchobatus and Taeniurops), whereas $50 \%$ (14 of 28) are still present being represented by at least one species. For instance, the genera Squalus and Myliobatis are currently represented in the Mediterranean Sea by the picked dogfish shark S. acanthias and the common eagle ray M. aquila (Compagno 1988; Last 


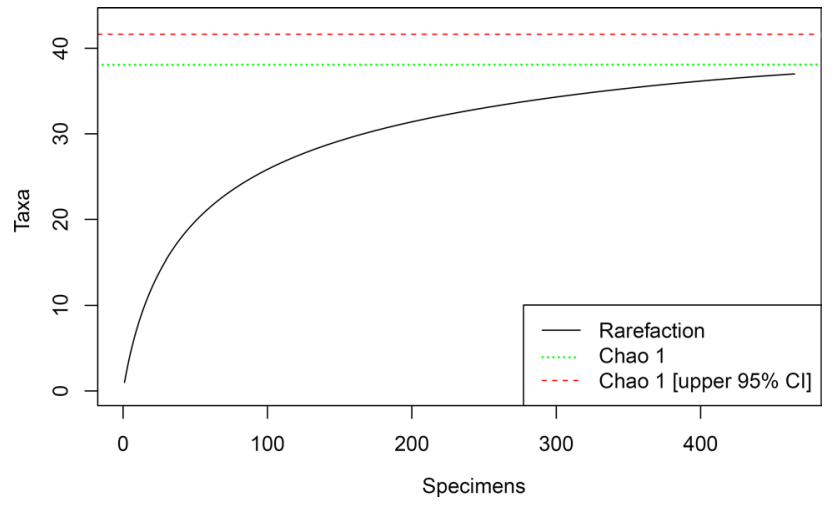

Fig. 10 Rarefaction curve and taxonomic richness of the chondrichthyan fauna from Simssee

et al. 2016). At the species level, all the recognized species but one (i.e. Centrophorus granulosus) are globally extinct. Although most of the recognized species have disappeared from the Mediterranean Sea, different biogeographic dynamics are observed by considering replacement by congeneric species. Fifty-five percent (11 of 20) of the extinct species were not replaced by congeneric species living today in the Mediterranean Sea. On the contrary, 45\% (9 of 20) of the extinct species have been substituted by at least one congeneric species living in the present-day Mediterranean Sea. For instance, Alopias exigua is globally extinct, but the extant thresher shark Alopias vulpinus currently occurs in the Mediterranean Sea (Compagno et al. 2005). All these biogeographic dynamics could have been influenced by intense tectonic, climatic and oceanographic events during the early Miocene of Europe (Rögl 1999). According to Kroh (2007), the climatic and oceanographic changes (i.e. drop of temperature and sea level changes) were the major factors controlling the distribution of echinoderm faunas during the early Miocene of the Central Paratethys, and may have also affected elasmobranchs. This idea was previously hypothesized as a possible cause of chondrichthyan distributional changes in South American localities during the Neogene (Long 1993; Cione et al. 2007; Carrillo-Briceño et al. 2013; Villafaña 2015; Partarrieu et al. 2018; Villafaña and Rivadeneira, 2014, 2018; Villafaña et al. 2019).

\section{Faunal comparison during the early Miocene}

According to our faunal comparison, the fauna from the Simssee area was more similar to closely adjacent localities in Europe rather than to other localities (Fig. 11 and Table 2). The most similar faunas are from Switzerland (76\%), Austria (71\%), France (62\%), North Germany (59\%) and Portugal (59\%). These high similarities could be related to the shorter

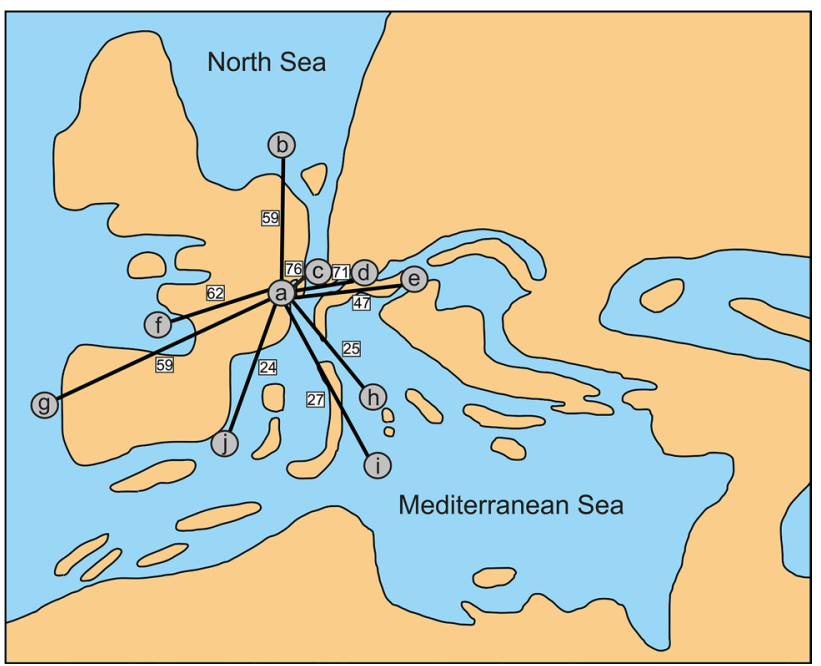

Fig. 11 Paleogeographic distribution and faunal similarity between the Simssee fauna and others early Miocene faunas. Simssee (a), Northern Germany (b), Switzerland (c), Austria (d), Slovakia (e), France (f), Portugal (g), Italy (h), Malta (i) and Spain (j). Map based on Rögl (1999)

distances and connection between the localities. During the Ottnangian, the western and Central Paratethys were connected through the Rhine Graben (Rögl 1999). According to Kocsis (2007), the presence of deep-water sharks such as Mitsukurina and Isistius should be the evidence of large and connected open water surfaces, with deeper sea basin during the Eggenburgian-Ottnangian stages. According to Pollerspöck and Straube (2017), the diversity of fishes from the Paratethys was shaped by immigration of taxa from other marine ecosystems and favoured by oceanographic variables such as salinity and oxygen contents. Additionally, dispersal of some sharks could be also possible into freshwater environment (Kocsis et al. 2007). Therefore, the seaway passages could have favoured the connection of elasmobranch faunas from different localities and explain their similarities. On the contrary, the faunas with the lowest similarities were from Colombia (20\%), Panamá (23\%), Spain (24\%) and Brazil (24\%), possibly reflecting to the long distances between the localities. Despite the apparent connection of Italy, Malta, and Spain with southern Germany during the Ottnangian (Rögl 1999), their lower similarity could be affected by sampling biases (i.e. incompleteness of the taxonomic inventories). However, areas where sampling is expected to be high (e.g. the Pacific coast of USA, Australia) also show low similarity values, due to the relatively low generic richness. In the case of India (29\%), the seaway passage between the Indo-Pacific and the Paratethys was closed during the Ottnangian, probably explaining its lower similarity to the fauna from Simssee. 
Table 2 Faunal similarity between the Simsee fauna and other early Miocene faunas

\begin{tabular}{|c|c|c|c|c|c|c|}
\hline Country & Combined localities & Stages & $\begin{array}{l}\text { Num- } \\
\text { ber of } \\
\text { genera }\end{array}$ & Shared genera & $\begin{array}{l}\text { Dice's } \\
\text { Similar- } \\
\text { ity }\end{array}$ & References \\
\hline Switzerland & $\begin{array}{l}\text { Benken, Zurich; Lucerne, } \\
\text { Gallen }\end{array}$ & Burdigalian & 41 & 27 & 0.76 & $\begin{array}{l}\text { Fischli (1930), Bolliger et al. } \\
\quad \text { (1995) and Jost et al. (2016) }\end{array}$ \\
\hline Austria & $\begin{array}{l}\text { Eggenburg, Maigen, } \\
\text { Kletzenmarkt, Oberöster- } \\
\text { reich, Plesching, Wallern }\end{array}$ & Eggenburgian-Ottnangian & 46 & 27 & 0.71 & $\begin{array}{l}\text { Schultz (2013) and Poller- } \\
\text { spock et al. (2018) }\end{array}$ \\
\hline France & $\begin{array}{l}\text { Bordeaux, Breyra Valley, } \\
\text { Gironde, Léognan, Mont- } \\
\text { pellier, Saucats }\end{array}$ & Aquitanian-Burdigalian & 41 & 22 & 0.62 & $\begin{array}{l}\text { Chevalier (1961), Cappetta } \\
\text { (1970), Cahuzac et al. } \\
\text { (2007) and Goedert et al. } \\
\text { (2017) }\end{array}$ \\
\hline North Germany & Werder, Uesen & Burdigalian & 38 & 20 & 0.59 & Reinecke et al. (2011) \\
\hline Portugal & $\begin{array}{l}\text { Quarry Quinta das Pedreiras, } \\
\text { do Narigao, da Noiva }\end{array}$ & Aquitanian-Burdigalian & 28 & 17 & 0.59 & Zbyszewski (1949) \\
\hline USA-east & $\begin{array}{l}\text { Calvert County, Cumberland } \\
\text { County, Harbourtown } \\
\text { Marina }\end{array}$ & Aquitanian-Burdigalian & 33 & 17 & 0.54 & $\begin{array}{l}\text { Cope (1870), Eastman (1904) } \\
\text { and Case (1980) }\end{array}$ \\
\hline Slovakia & Cerova, Lieskove & Burdigalian & 30 & 14 & 0.47 & $\begin{array}{l}\text { Underwood and Schlogl } \\
\text { (2013) }\end{array}$ \\
\hline Hungary & Ipolytarnoc & Burdigalian & 20 & 10 & 0.40 & $\begin{array}{l}\text { Kordos and Solt (1984) and } \\
\text { Kocsis (2007) }\end{array}$ \\
\hline Chile & La Boca, Punta Perro & Aquitanian-Burdigalian & 12 & 8 & 0.38 & Suarez et al. (2006) \\
\hline India & Baripada, Gogha & Aquitanian-Burdigalian & 18 & 7 & 0.29 & $\begin{array}{l}\text { Eames (1937) and Sahni } \\
\text { (1979) }\end{array}$ \\
\hline USA-west & Point Arena, Jewett Sand & Aquitanian & 12 & 6 & 0.29 & $\begin{array}{l}\text { Philips and Welton (1976) and } \\
\text { Welton (1981) }\end{array}$ \\
\hline Malta & $\begin{array}{l}\text { Ras ir-Reqqa, Bahrija, Rdum } \\
\text { ii-Vigarju }\end{array}$ & Aquitanian-Burdigalian & 15 & 6 & 0.27 & Ward and Bonavia (2001) \\
\hline Australia & Strathalbyn & Aquitanian-Burdigalian & 10 & 5 & 0.25 & Pledge (1967) \\
\hline Italy & Montagna della Maiella & Burdigalian & 10 & 5 & 0.25 & Marsili et al. (2007) \\
\hline Brazil & $\begin{array}{l}\text { Colonia Pedro Teixeira, } \\
\text { Jazida, Praia de Fortalez- } \\
\text { inha }\end{array}$ & Aquitanian-Burdigalian & 11 & 5 & 0.24 & Araujo-Tavora et al. (2010) \\
\hline Spain & Elche, Cala Sant Vicenç & Burdigalian & 11 & 5 & 0.24 & $\begin{array}{l}\text { Mendiola (1996, 1997), } \\
\text { Vicens and Rodriguez } \\
\text { (2003) and Mas (2009) }\end{array}$ \\
\hline Panama & $\begin{array}{l}\text { Cartagena, Las Cascadas, } \\
\text { Lirio, Pacuare de Tres } \\
\text { Equis }\end{array}$ & Aquitanian-Burdigalian & 13 & 5 & 0.23 & $\begin{array}{l}\text { Pimiento et al. (2013) and } \\
\text { Laurito et al. (2014) }\end{array}$ \\
\hline Colombia & Arroyo Uitpa & Aquitanian & 11 & 4 & 0.20 & $\begin{array}{l}\text { Carrillo-Briceño et al. (2016a, } \\
\text { b) }\end{array}$ \\
\hline
\end{tabular}

Acknowledgements Open access funding provided by Austrian Science Fund (FWF). We thank S. Schellhorn (Gaissach, Germany) and N. Rückert-Ülkümen (Bayerische Staatssammlung für Paläontologie und Geologie, Munich, Germany) for providing some material that they collected for this study. We deeply appreciate the help provided by B. Beaury. J.A.V. was supported by the Comisisión Nacional de Investigación Científica y Tecnológica (CONICYT), amd; G. M. by the Austrian Science Fund (FWF) [M2368-B25].
Funding This research was supported by Becas de Doctorado en el Extranjero, Becas Chile (Grant 72160271).

Open Access This article is licensed under a Creative Commons Attribution 4.0 International License, which permits use, sharing, adaptation, distribution and reproduction in any medium or format, as long as you give appropriate credit to the original author(s) and the source, provide a link to the Creative Commons licence, and indicate if changes were made. The images or other third party material in this article are 
included in the article's Creative Commons licence, unless indicated otherwise in a credit line to the material. If material is not included in the article's Creative Commons licence and your intended use is not permitted by statutory regulation or exceeds the permitted use, you will need to obtain permission directly from the copyright holder. To view a copy of this licence, visit http://creativecommons.org/licenses/by/4.0/.

\section{References}

Agassiz, L. 1833-1884. Recherches sur les poissons fossiles. Neuchâtel: Petitpierre.

Agassiz, L. 1858. Remarks on a new species of skate from the Sandwich islands. Proceedings of the Boston Society of Natural History 6: $1-385$.

Aguilera, O., and D.R. de Aguilera. 2004. Giant-toothed white sharks and wide-toothed mako (Lamnidae) from the Venezuela Neogene: their role in the Caribbean, shallow-water fish assemblage. Caribbean Journal of Science 40(3): 368-382.

Akhilesh, K.V., M. Hashim, K.K. Bineesh, C.P.R. Shanis, and U. Ganga. 2010. New distributional records of deep-sea sharks from Indian waters. Journal of the Marine Biological Association of India 52(1): 29-34.

Antunes, M.T., and S. Jonet. 1970. Requins de l'Helvétien supérieur et du Tortonien de Lisbonne. Revista de Faculdade de Ciências de Lisboa 16: 119-280.

Antunes, M.T., S. Jonet, and A. Nascimento. 1981. Vertébrés (Crocodiliens, Poissons) du Miocène marin de l'Algarve occidentale. Ciencias da Terra (UNL) 6: 9-38.

Ayres, W.O. 1855. Description of new species of California fishes. Proceedings of the California Academy of Sciences 1: 23-77.

Baier, J., K.H. Schmitt, and R. Mick. 2004. Notizen zur untermiozänen Hai- und Rochenfauna der Erminger Turritellenplatte (Mittlere Schwäbische Alb, SW-Deutschland). Jahresberichte und Mitteilungen des Oberrheinischen Geologischen Vereins 86: 361-371.

Baldi, T. 1980. The early history of the Paratethys. Bulletin of the Hungarian Geological Society 110(3-4): 468-471.

Barthelt, D., O. Fejfar, F.H. Pfeil, and E. Unger. 1991. Notizen zu einem Profil der Selachier-Fundstelle Walbertsweiler im Bereich der miozänen Oberen Meeresmolasse Süddeutschlands. Münchner geowissenschaftliche Abhandlungen (A: Geologie und Paläontologie) 19: 195-208.

Berg, L.S. 1937. A classification of fish-like vertebrates. Bulletin de l'Académie des Sciences de l'URSS 4: 1277-1280.

Berg, L.S. 1958. System der rezenten und fossilen Fischartigen und Fische. Berlin: VEB Deutscher Verlag der Wissenschaften.

Bianucci, G., A. Collareta, G. Bosio, W. Landini, K. Gariboldi, A. Gioncada, O. Lambert, E. Malinverno, C. de Muizon, R. VarasMalca, I. Maria Villa, G. Coletti, M. Urbina, and C. Di Celma. 2018. Taphonomy and palaeoecology of the lower Miocene marine vertebrate assemblage of Ullujaya (Chilcatay Formation, East Pisco Basin, southern Peru). Palaeogeography, Palaeoclimatology, Palaeoecology 511: 256-279.

Blainville, H.M.D. de 1816. Prodrome d'une distribution systématique du règne animal. Bulletin de la Société Philomathique de Paris 8: $105-124$

Bleeker, P. 1859. Enumeratio specierum fiscium hucusque in Archipelago indico observatarum. Acta de la Société du Science d'IndoNeerland 6: 1-276.

Bloch, M.E., and J.G. Schneider. 1801. Blochii Systema Ichthyologiae iconibus ex illustratum. Post obitum auctoris opus inchoatum absolvit, correxit, interpolavit. Gottlob Schneider, Saxo. Berolini: Sumtibus Austoris Impressum et Bibliopolio Sanderiano Commissum.
Boessenecker, R.W., D.J. Ehret, D.J. Long, M. Churchill, E. Martin, and S.J. Boessenecker. 2019. The Early Pliocene extinction of the mega-toothed shark Otodus megalodon: a view from the eastern North Pacific. PeerJ 7: e6088.

Bolliger, T., R. Kindlimann, and U. Wegmüller. 1995. Die marinen Sedimente (jüngere OMM, St. Galler-Formation) am Südwestrand der Hörnlischüttung (Ostschweiz) und die palökologische Interpretation ihres Fossilinhaltes. Eclogae Geologicae Helvetiae 88(3): 885-909.

Bonaparte, C.L. 1834. Iconografia della fauna italica per Ie quattro classi degli animali vertebrati. Rome: Tip. Salviucci.

Bonaparte, C.L. 1838. Selachorum tabula analytica. Nuovi Annali delle Scienze Naturali Bologna 1: 195-214.

Bracher H, and E. Unger. 2007. Untermiozäne Haie und Rochen. Altheim.

Brzobohatý, R., and O. Schultz. 1971. Die Fischfauna der Eggenburger Schichtengruppe. In M1 Eggenburgien. Die Eggenburger Schichtengruppe und ihr Stratotypus. Chronostratigraphie und Neostratotypen Miozän der zentralen Paratethys, eds. F. Steininger, J. Senes, T. Báldi, E. Brestenská, R. Brzobohatý, I. Cicha, P. Ctyroký, J. Ctyroká, G. Daxner-Höck, K. Kollmann, R. Lehotayová, A. Ondrejíckoá, A. Papp, E. Planderová, O. Schultz, and I. Zapletalová, 719-759. Bratislava: Vydavatel'stvo Slovenskej Akadémie Vied.

Buen, F. de. 1926. Catalogo ictiologico del Mediterraneo espanol y de Marruecos recopilando 10 publicado sobre peces de las costas mediterranea y proximas del Atlantico (Mar de Espana). Resultado de las campañas realizadas por acuerdos internacionales 2: $1-221$

Canevet, J.M. 2011. Les Chondrichthyens du Miocène moyen (Serravallien) de Salles (Gironde, France). Cossmanniana 13: 59-76.

Cappetta, H. 1970. Les sélaciens du Miocène de la région de Montpellier. Palaeovertebrata, Memoire extraordinaire: 1-139

Cappetta, H. 1973. Les sélaciens du Burdigalien de lespignan (Hérault). Geobios 6(3): 211-223.

Cappetta, H. 1975. Les Sélaciens miocènes du Midi de la France, répartition stratigraphique et bathymétrique. In 3 ème réunion annuelle des Sciences de la Terre, p. 90. Montpellier.

Cappetta, H. 1980. Modification du statut generique de quelques especes de selaciens cretaces et tertiaires. Palaeovertebrata 10 (1): 29-42.

Cappetta, H. 2012. Chondrichthyes: Mesozoic and Cenozoic Elasmobranchii: Teeth Handbook of Paleoichthyology, 3E. München: F. Pfeil.

Carrillo-Briceño, J.D., G. Gonzalez-Barba, M.G. Landaeta, and S.N. Nielsen. 2013. Condrictios fósiles del Plioceno superior de la Formación Horcón, Región de Valparaíso, Chile central. Revista chilena de historia natural 86(2): 191-206.

Carrillo-Briceño, J.D., O.A. Aguilera, and F. Rodriguez. 2014. Fossil Chondrichthyes from the central eastern Pacific Ocean and their paleoceanographic significance. Journal of South American Earth Sciences 51: 76-90.

Carrillo-Briceño, J.D., T. Argyriou, V. Zapata, R. Kindlimann, and C. Jaramillo. 2016a. A new early Miocene (Aquitanian) elasmobranchii assemblage from the la Guajira Peninsula, Colombia. Ameghiniana 53(2): 77-100.

Carrillo-Briceño, J.D., O.A. Aguilera, C. De Gracia, G. AguirreFernández, R. Kindlimann, and M.R. Sánchez-Villagra. 2016. An early Neogene elasmobranch fauna from the southern Caribbean (western Venezuela). Palaeontologia Electronica 19: (19.2).

Cartamil, D., N.C. Wegner, D. Kacev, N. Ben-Aderet, S. Kohin, and J.B. Graham. 2010. Movement patterns and nursery habitat of juvenile thresher sharks Alopias vulpinus in the Southern California Bight. Marine Ecology Progress Series 404: 249-258. 
Case, G.R. 1980. A Selachian Fauna from the Trent Formation, Lower Miocene (Aquitanian) of Eastern North Carolina. Palaeontographica (Abteilung A) 171: 75-103.

Chao, A., and S.M. Lee. 1992. Estimating the Number of Classes Via Sample Coverage. Journal of the American Statistical Association 87(417): 210-217.

Cione, A.L., J.A. Mennucci, F. Santalucita, and C.A. Hospitaleche. 2007. Local extinction of sharks of genus Carcharias Rafinesque, 1810 (Elasmobranchii, Odontaspididae) in the eastern Pacific Ocean. Andean Geology 34(1): 139-145.

Cione, A.L., D.A. Cabrera, and M.J. Barla. 2012. Oldest record of the great white shark (Lamnidae, Carcharodon; Miocene) in the Southern Atlantic. Geobios 45(2): 167-172.

Claeson, K.M., M.A. O’Leary, E.M. Roberts, F. Sissoko, M. Bouaré, L. Tapanila, D. Goodwin, and M.D. Gottfried. 2010. First Mesozoic record of the stingray Myliobatis wurnoensis from Mali and a phylogenetic analysis of Myliobatidae incorporating dental characters. Acta Palaeontologica Polonica 55 (4): 655-675.

Colwell, R.K., and J.A. Coddington. 1994. Estimating terrestrial biodiversity through extrapolation. Philosophical Transactions of the Royal Society of London. Series B: Biological Sciences 345(1311): 101-118.

Comapgno, L.J.V. 1984b. FAO species catalogue. Vol 4. Sharks of the world. An annotated and illustrated catalogue of shark species known to date. Part 2. Carcharhiniformes. FAO Fisheries Synopsis 125: 251-655.

Compagno, L.J.V. 1973. Interrelationships of living elasmobranchs. In Interrelationships of Fishes, eds. P.H. Greenwood, R.S Miles and C. Patterson. Zoological Journal of Linnean Society 53 (Supplement 1): 15-61.

Compagno, L.J.V. 1977. Phyletic relationships of living sharks and rays. American Zoologist 17: 303-322.

Compagno, L.J.V. 1984a. FAO species catalogue. Vol 4. Sharks of the world. An annotated and illustrated catalogue of shark species known to date. Part 1. Hexanchiformes to Lamniformes. FAO Fisheries Synopsis 125: 1-249.

Compagno, L.J.V. 1998. Pristiophoridae. Saw sharks. In FAO Identification Guide for Fishery Purposes. The Living Marine Resources of the Western Central Pacific, eds. K.E. Carpenter and V.H. Niem. Rome: FAO.

Compagno, L.J.V. 2001. Sharks of the world. An annotated and illustrated catalogue of shark species known to date. Vol. 2.: Bullhead, mackerel and carpet sharks (Heterodontiformes, Lamniformes and Orectolobiformes, Rome: FAO.

Compagno, L.J.V., D.A. Ebert, and M.J. Smale. 1989. Guide to the sharks and rays of southern Africa. London: New Holland Ltd.

Compagno, L.J.V., M. Dando, and S. Fowler. 2005. A field guide to the sharks of the World. London: HarperCollins.

Conrath, C.L., and J.A. Musick. 2010. Residency, space use and movement patterns of juvenile sandbar sharks (Carcharhinus plumbeus) within a Virginia summer nursery area. Marine and Freshwater Research 61(2): 223-235.

Cook, T.D., M.V. Wilson, and M.G. Newbrey. 2010. The first record of the large Cretaceous lamniform shark, Cardabiodon ricki, from North America and a new empirical test for its presumed antitropical distribution. Journal of Vertebrate Paleontology 30(3): 643-649.

Cowley, P.D., and L.J.V. Compagno. 1993. A taxonomic re-evaluation of the blue stingray from southern Africa (Myliobatiformes: Dasyatidae). South African Journal of Marine Science 13: $135-149$.

Cuvier, G. 1817. Le Regne Animal distribue d'apres son organisation pour servir de base 11 I'histoire naturelle des animaux et d'introduction 11 I'anatomie compare. Les reptiles, les poissons, les mollusques et les annelides. Paris: A. Belin.
Cuvier, G. 1829. Le Règne Animal, distribué d'aprés son organisation, pour servir de base à l'histoire naturelle des animaux et dintroduction à l'anatimie comparée. Paris: Déterville.

Dumeril, A.M.C. 1806. Zoologie analytique, ou methode naturelle de classification des animaux. Paris: Librairie Allais.

Ebert, D.A., and L.J. Compagno. 2009. Chlamydoselachus africana, a new species of frilled shark from southern Africa (Chondrichthyes, Hexanchiformes, Chlamydoselachidae). Zootaxa 2173: $1-18$.

Ebert, D.A., and M.F.W. Stehmann. 2013. Sharks, batoids and chimaeras of the North Atlantic. In FAO Species Catalogue for Fishery Purposes, vol. 7. Rome: FAO.

Ebert, D.A., S. Fowler, and L.J.V. Compagno. 2013. Sharks of the World: A Fully Illustrated Guide. London: Wild Nature Press.

Ehret, D.J., B.J. Macfadden, D.S. Jones, T.J. Devries, D.A. Foster, and R. Salas-Gismondi. 2012. Origin of the white shark Carcharodon (Lamniformes: Lamnidae) based on recalibration of the Upper Neogene Pisco Formation of Peru. Palaeontology 55(6): 1139-1153.

Emry, R.J., and R.E. Eshelman. 1998. The early Hemingfordian (early Miocene) Pollack Farm local fauna: First Tertiary land mammals described from Delaware. Geology and paleontology of the lower Miocene Pollack Farm Fossil Site, Delaware. Delaware Geological Survey Special Publication 21: 153-173.

Engelbrecht, A., T. Mörs, M.A. Reguero, and J. Kriwet. 2017. A new sawshark, Pristiophorus laevis, from the Eocene of Antarctica with comments on Pristiophorus lanceolatus. Historical Biology 29(6): 841-853.

Ergüden, D., D. Ayas, M. Gürlek, S. Karan, and C. Turan. 2019. First documented smoothback angelshark Squatina oculata Bonaparte, 1840 from the North-Eastern Mediterranean Sea, Turkey. Cahiers de Biologie Marine 60: 189-194.

Euphrasen, B.A. 1790. Raja (Narinari) beskrifven. Kongliga Vetenskaps Akademiens nya Handlingar Stockholm 11: 217-219.

Figueiredo Petean, F. de, and M.R. de Carvalho. 2018. Comparative morphology and systematics of the cookiecutter sharks genus Isistius Gill (1864) (Chrondrichthyes: Squaliformes:Dalatiidae). PLoS ONE 13(8): e0201913.

Fischli, H. 1930. Die Fossilien der Quarzsande von Benken (Kt. Zürich). Mitteilungen der Naturwissenschaftlichen Gesellschaft in Winterthur 17(18): 131-167.

Fitzgerald, E.M. 2004. A review of the Tertiary fossil Cetacea (Mammalia) localities in Australia. Memoirs of Museum Victoria 61(2): 183-208.

Froese, R., and D. Pauly. 2019. FishBase. World Wide Web electronic publication. www.fishbase.org version (08/2019)

Fulgosi, F.C., S. Casati, A. Orlandini, and D. Persico. 2009. A small fossil fish fauna, rich in Chlamydoselachus teeth, from the Late Pliocene of Tuscany (Siena, central Italy). Cainozoic Research 6(1/2): 3-23.

Garibaldi, F., and L. Orsi Relini. 2012. Record of Carcharhinus falciformis (Bibron in Müller \& Henle, 1839), in Italian waters (Ligurian Sea, Northwestern Mediterranean). Cybium 36 (2): 399-400.

Garman, S. 1884. An extraordinary shark. Bulletin of the Essex Institute 16: 47-55.

Garman, S. 1913. The Plagiostomia (Sharks, Skates and Rays). Memoirs of the Museum of Comparative Zoology at Harvard College 36: $1-528$.

Gibbes, R.W. 1849. Monograph of the fossil Squalidae of the United States. Journal of the Academy of Natural Sciences of Philadelphia [14] 1(3): 191-206.

Gill, T. 1862. Analytical synopsis of the order of Squali and revision and nomenclature of genera. Annals of the Society of Natural History of New York 7: 367-408. 
Gill, T. 1864. Second contribution to the selachology of California. Proceedings of the Academy of Natural Sciences of Philadelphia 16: 147-151.

Gill, T. 1872. Arrangement of the families of fishes, or classes Pisces, Marsipobranchii, and Leptocardii. Smithsonian Miscellaneous Collections 247: 1-49.

Gillette, D.D. 1984. A marine ichthyofauna from the Miocene of Panama, and the Tertiary Caribbean faunal province. Journal of Vertebrate Paleontology 4(2): 172-186.

Glikman, T.N. 1964. Sharks of Paleogene and their stratitraphic significance. Moskva: Nauka Press. (in Russian).

Goedert, J., R. Amiot, F. Arnaud-Godet, G. Cuny, F. Fourel, J.A. Hernandez, U. Pedreira-Segade, and C. Lécuyer. 2017. Miocene (Burdigalian) seawater and air temperatures estimated from the geochemistry of fossil remains from the Aquitaine Basin, France. Palaeogeography, Palaeoclimatology, Palaeoecology 481: 14-28.

Goodrich, E.S. 1909. Vertebrata Craniata. I. Cyclostomes and fishes. In A Treatise on Zoology, eds. A.E. Magurran and B.J. McGill. London: Adam a. Charles Black.

Gotelli, Nicholas J., and Robert K. Colwell. 2011. Estimating species richness. In Biological diversity: frontiers in measurement and assessment, eds. A.E. Magurran and B.J. McGill, 39-54. Oxford: Oxford University Press.

Gray, J.E. 1851. List of the specimens of fish in the collection of the British Museum. Part I. Chondropterygii. London: British Museum. (Natural History).

Guinot, G., S. Adnet, and H. Cappetta. 2012. An analytical approach for estimating fossil record and diversification events in sharks, skates and rays. PLOS ONE 7: e44632.

Hammer, Ø., and D.A.T. Harper. 2006. Paleontological data analysis. Malden: Blackwell Publishing.

Haq, B.U., J. Hardenbol, and P.R. Vail. 1988. Mesozoic and Cenozoic chronostratigraphy and cycles of sea-level changes. In Sea-level changes: an integrated approach, eds. Wilgus, C. K. Hastings, B.S., Kendall, C.G.St.C., Posamentier, H.W., Ross, C.A., Van Wagoner J.C. Society of Economic Paleontologist and Mineralogists, Special Publication 42: 71-108.

Haye, T., T. Reinecke, K. Gürs, and A. Piehl. 2008. Die Elasmobranchier des Neochattiums (Oberoligozän) von Johannistal, Ostholstein, und Ergänzungen zu deren Vorkommen in der RatzeburgFormation (Neochattium) des südöstlichen Nordseebeckens. Palaeontos 14: 55-95.

Hilaire, Geoffroy Saint E. 1817. Poissons du Nil, de la Mer Rouge et de la Mediterranee. In Description de I' Egypte; ou, Recueil des observations et des recherches qui ont ete faites en Egypte pendant I'expedition de I'armee frant; aise, publie par les ordres de sa Majeste-L'Empereur Napoleon Ie Grand, vol. 1, ed. J. Savigni, 265-310. Paris: Imprimerie impériale.

Holec, P., M. Hornacek, and M. Sykora. 1995. Lower Miocene Shark (Chondrichthyes, Elasmobranchii) and Whale Faunas (Mammalia, Cetacea) near Mučín, Southern Slovakia. Geologické Práce, Správy 100: 37-52.

Höltke, O. 2014. Haifischbecken Ursendorf. Fossilien 2014(2):: 20-25.

Hovestadt, D.C., and M. Hovestadt-Euler. 2013. Generic assessment and reallocation of Cenozoic Myliobatinae based on new information of tooth, tooth plate and caudal spine morphology of extant taxa. Palaeontos 24: 1-66.

Hubalek, Z. 1982. Coefficients of association and similarity, based on binary (presence-absence) data: an evaluation. Biological Reviews 57: 669-689.

Huxley, T.H. 1880. On the application of the laws of evolution to the arrangement of the Vertebrata and more particularly of the Mammalia. Proceedings of the Zoological Society of London 1880: 649-662.
Ihering, H. von 1927. Die miocäne Selachierfauna von Schwaben und ihre Beziehungen zu anderen Tertiärfaunen. Neues Jahrbuch für Mineralogie, Geologie und Paläontologie, Beilage 57: 466-503.

Joleaud, L. 1907-1912. Géologie et Paléontologie de la Plaine du Comtat et de ses abords. Description des terrains Néogènes. Mémoires de l'Academie Vaucluse 1-2: 1-285.

Jonet, S. 1996. Notes d 'ichthyologie Miocene. II. Les Carcharhinidae. Boletim do Museu e Laboratorio Mineralógico e Geológico da Faculdade de Ciências 10(2): 65-88.

Jordan, D.S. 1888. Description of two new species of fishes from South America. Proceedings of the Academy of Natural Sciences of Philadelphia 39: 387-388.

Jordan, D.S. 1898. Description of a species of fish (Mitsukurina owstoni) from Japan, the type of a distinct family of lamnoid sharks. Proceedings of the California Academy of Sciences 1: 199-202.

Jordan, D.S., and B.W. Evermann. 1896. The fishes of North and Middle America, a descriptive catalogue of the species of fish-like vertebrates found in the waters of North America, north of the isthmus of Panama. Part. I. Bulletin of the United States National Museum 47: 2183-3136.

Jordan, D.S., and J.O. Snyder. 1902. Descriptions of two new species of squaloid sharks from Japan. Proceedings of the United States National Museum 25(1279): 79-87.

Jost, L., A. Chao, and R.L. Chazdon. 2011. Compositional similarity and $\beta$ (beta) diversity. In Biological diversity: frontiers in measurement and assessment, eds. A.E. Magurran and B.J. McGill. Oxford: Oxford University Press.

Jost, J., O. Kempf, and D. Kälin. 2016. Stratigraphy and palaeoecology of the Upper Marine Molasse (OMM) of the central Swiss Plateau. Swiss Journal of Geosciences 109(2): 149-169.

Kent, B.W. 2018. The cartilaginous fishes (chimaeras, sharks and rays) of Calvert Cliffs, Maryland, USA. In Geology and Vertebrate Paleontology of Calvert Cliffs, ed. B.W. Kent. Washington: Smithsonian Institution Press.

Klug, S., and J. Kriwet. 2013. Node age estimations and the origin of angel sharks, Squatiniformes (Neoselachii, Squalomorphii). Journal of Systematic Palaeontology 11(1): 91-110.

Koch, A. 1904. Fossile Haifischzähne und Säugetierreste von Felsöesztergály, im Komitate Nógrád. Földtani Közlöny 34: 260-273.

Kocsis, L. 2007. Central paratethyan shark fauna (Ipolytarnóc, Hungary). Geologica Carpathica 58(1): 27-40.

Kocsis, L., T.W. Vennemann, and D. Fontignie. 2007. Migration of sharks into freshwater systems during the Miocene and implications for Alpine paleoelevation. Geology 35(5): 451-454.

Kordos L., and P. Solt. 1982. A magyarországi miocén tengeri gerinces faunaszintek vázlata. A Magyar Állami Földtani Intézet Évi Jelentése 347-351.

Kriwet, J. 2005. Additions to the Eocene selachian fauna of Antarctica with comments on Antarctic selachian diversity. Journal of Vertebrate Paleontology 25(1): 1-7.

Kroh, A. 2007. Climate changes in the Early to Middle Miocene of the Central Paratethys and the origin of its echinoderm fauna. Palaeogeography, Palaeoclimatology, Palaeoecology 253(1-2): 169-207.

Lalaï, D. 1986. Nouvelles faunes de Rongeurs de la fin du Miocène inférieur en Provence. Implications géologiques et paléogéographiques. Palaeovertebrata 16(2): 77-126.

Landini, W., A. Collareta, C. Di Celma, E. Malinverno, M. Urbina, and G. Bianucci. 2019. The early Miocene elasmobranch assemblage from Zamaca (Chilcatay Formation, Peru). Journal of South American Earth Sciences 91: 352-371.

Last, P.R., and J.D. Stevens. 1994. Sharks and Rays of Australia, 2nd ed. Melbourne: CSIRO Publishing. 
Last, P., W. White, M. de Carvalho, B. Séret, M. Stehmann, and G. Naylor. 2016. Rays of the World. Clayton: CSIRO Publishing.

Latham, J. 1794. An essay on the various species of Sawfish. Transactions of the Linnean Society of London 2(25): 273-282.

Laurito, C.A. 1997. El Género Isistius (Squalidae) en el alto Guayacán. Formación Uscari (Mioceno superior-Plioceno Inferior), Provincia de Limón, Costa Rica. Revista Geológica de América Central 19(20): 87-92.

Laurito, C.A., C. Calvo, A.L. Valerio, A. Calvo, and R. Chacón. 2014. Ictiofauna del Mioceno Inferior de la localidad de Pacuare de Tres Equis, Formación Río Banano, provincia de Cartago, Costa Rica, y descripción de un nuevo género y una nueva especie de Scaridae. Revista Geológica de América Central 50: 153-192.

Laurito Mora, C.A. 1999. Los Seláceos fósiles de la localidad de Alto Guayacán (y otros ictiolitos asociados): Mioceno-SuperiorPlioceno Inferior de la formación Uscari. Provincia de Limón, Costa Rica. San José: CA Laurito.

Ledoux, J.C. 1972. Les Squalidae (Euselachii) miocenes des environs d'Avignon (Vaucluse). Documents des Laboratoires de Géologie de la Faculté des Sciences de Lyon 52: 133-175.

Leriche, M. 1927. Les Poissons de la Molasse suisse. Prémiere fascicule. Mémoires de la Société paléontologique Suisse 46: 1-55.

Linnaeus, C. 1758. Systema Naturae per Regna Tria Naturae: secundum classes, ordines, genera, species, cum charcteribus differentiis synonymis, locis, 10th ed. Holmiae: Laurentius Salvius.

Long, D.J. 1993. Late Miocene and Early Pliocene fish assemblages from the north central coast of Chile. Tertiary Research 14(3): $117-126$.

Long, D. J., R.W. Boessenecker, and D.J. Ehret. 2014. Timing of evolution in the Carcharodon lineage: Rapid morphological change creates a major shift in a predator's trophic niche. In Meeting Program and Abstracts of the 2nd Annual Sharks International Conference, Durban, South Africa, p. 123.

Lutzeier, H. 1922. Beiträge zur Kenntnis der Meeresmolasse in der Ulmer Gegend. Neues Jahrbuch für Mineralogie Geologie und Paläontologie 1922: 117-180.

Maisch IV, H.M., M.A. Becker, and J.A. Chamberlain. 2018. Lamniform and Carcharhiniform Sharks from the Pungo River and Yorktown Formations (Miocene-Pliocene) of the Submerged Continental Shelf, Onslow Bay, North Carolina, USA. Copeia 106 (2): 353-374.

Marsili, S. 2007. A new bathyal shark fauna from the Pleistocene sediments of Fiumefreddo (Sicily, Italy). Geodiversitas 29(2): 229-247.

Marsili, S., G. Carnevale, E. Danese, G. Bianucci, and W. Landini. 2007. Early Miocene vertebrates from Montagna della Maiella, Italy. Annales de Paléontologie 93: 27-66.

McFarlane, G.A., and J.R. King. 2003. Migration patterns of spiny dogfish (Squalus acanthias) in the North Pacific Ocean. Fishery Bulletin 101(2): 358-367.

Meléndez, M.J., J.C. Báez, J.M. Serna-Quintero, J.A. Camiñas, I. de Loyola Fernández, R. Real, and D. Macías. 2017. Historical and ecological drivers of the spatial pattern of Chondrichthyes species richness in the Mediterranean Sea. PLoS ONE 12(4): $\mathrm{e} 0175699$.

Mondal, S., S. Das, S. Mallick, and D. Adhikary. 2009. Miocene shark teeth assemblages and ancillary fish taxa from Baripada, Orissa: Taxonomic revision and a global palaeobiogeographic overview. Journal of the Palaeontological Society of India 54(2): 1-135.

Müller, J., and J. Henle. 1837. Gattungen der Haifische und Rochen nach einer von ihm mit Hrn. Henle unternommenen gemeinschaftlichen Arbeit iiber die Naturgeschichte der Knorpelfische. Berichte der Königlichen Preussischen Akademie der Wissenschaften zu Berlin 2: 111-118.

Müller, J., and J. Henle. 1838. Ueber die Gattungen der Plagiostomen. Archiv für Naturgeschichte 4: 83-85.
Müller, J., and J. Henle. 1841. Systematische Beschreibung der Plagiostomen. Berlin: Veit.

Murguía, M., and J.L. Villaseñor. 2003. Estimating the effect of the similarity coefficient and the cluster algorithm on biogeographic classifications. Annales Botanici Fennici 40: 415-421.

Naylor, G.J.P., J.N. Caira, K. Jensen, K.A.M. Rosana, N. Straube, and C. Lakner. 2012. Elasmobranch phylogeny: A mitochondrial estimate based on 595 species. In Biology of Sharks and Rays and their Relatives, eds. J.C. Carrier, J.A. Musick, and M.R. Heithaus. Boca Raton: CRC Press.

Notarbartolo di Sciara, G., and I. Bianchi. 1998. Guida degli squali e delle razze del Mediterraneo. Padova: F. Muzzio.

Partarrieu, D., J.A. VillafañA, L. Pinto, F.A. Mourgues, P.A. OyanadelUrbina, M.M. Rivadeneira, and J.D. Carrillo-Briceño. 2018. Neogene 'Horn Sharks' Heterodontus (Chondrichthyes: Elasmobranchii) from the Southeastern Pacific and Their Paleoenvironmental Significance. Ameghiniana 55(6): 651-668.

Perez, V.J., and K.W. Marks. 2017. The first documented fossil records of Isistius and Squatina (Chondrichthyes) from Florida, with an overview of the associated vertebrate fauna. Bulletin of the Florida Museum of Natural History 55: 139-155.

Pfeil, F.H. 1983. Zahn morphologische Untersuchungen an rezenten und fossilen Haien der Ordnungen Chlamydoselachiformes und Echinorhiniformes. Palaeoichthyologica 1: 1-315.

Pfeil, F.H. 1991. Haie und Rochen aus Walbertsweiler. In Notizen zu einem Profil der Selachier-Fundstelle Walbertsweiler im Bereich der miozänen Oberen Meeresmolasse Süddeutschlands, eds. D. Barthelt, O. Fejfar., F.H. Pfeil, and E. Unger. Münchner geowissenschaftliche Abhandlungen (A: Geologie und Paläontologie) 19: 198-208.

Phillips, F.J., B.J. Welton, and J. Welton. 1976. Paleontologic studies of the middle Tertiary Skooner Gulch and Gallaway Formations at Point Arena, California. In Meeting Program and Abstracts of the The Neogene symposium, Society of Economic Paleontologists and Mineralogist Annual Meeting, San Francisco, United States, 137-154.

Piller, W.E., M. Harzhauser, and O. Mandic. 2007. Miocene Central Paratethys stratigraphy-current status and future directions. Stratigraphy 4: 151-168.

Pimiento, C., G. Gonzalez-Barba, A.J. Hendy, C. Jaramillo, B.J. MacFadden, C. Montes, and M. Shippritt. 2013. Early Miocene chondrichthyans from the Culebra Formation, Panama: a window into marine vertebrate faunas before closure the Central American Seaway. Journal of South American Earth Sciences 42: 159-170.

Pipper, M., B. Reichenbachert, W. Witt, and A. Rocholl. 2007. The Middle and Upper Ottnangian of the Simssee area (SE Germany): Micropalaeontology, biostratigraphy and chronostratigraphy. Neues Jahrbuch für Geologie und Paläontologie, Abhandlungen 245: 353-378.

Pledge, N.S. 1967. Fossil elasmobranch teeth of South Australia and their stratigraphic distribution. Transactions of the Royal Society of South Australia 91: 135-160.

Pollerspöck, J., and B. Beaury. 2014. Eine Elasmobranchierfauna (Elasmobranchii, Neoselachii) aus der Oberen Meeresmolasse (Ottnangium, Unteres Miozän) des Heigelsberger Grabens bei Teisendorf, Oberbayern. Zitteliana A54: 23-37.

Pollerspöck, J., and N. Straube. 2017. A new deep-sea elasmobranch fauna from the Central Paratethys (Neuhofener Beds, Mitterdorf, near Passau, Germany, Early Miocene, Middle Burdigalian). Zitteliana 90: 27-53.

Pollerspöck, J., and Straube, N. 2019. http://www.shark-references .com, World Wide Web electronic publication, Version 2019 [accessed: 26.04.2019].

Pollerspöck, J., C.K. Flammensbeck, and N. Straube. 2018. Palaeocentroscymnus (Chondrichthyes: Somniosidae), a new sleeper 
shark genus from Miocene deposits of Austria (Europe). PalZ. Paläontologische Zeitschrift 92(3): 443-456.

Probst, J. 1877. Beiträge zur Kenntniss der fossilen Fische aus der Molasse von Baltringen. II: Batoidei A. Günther. Jahreshefte des Vereins für vaterländische Naturkunde in Württemberg 33: 69-103.

Probst, J. 1879. Beiträge zur Kenntnis der fossilen Fische aus der Molasse von Baltringen IV. Jahreshefte des Vereins für Vaterländische Naturkunde in Württemberg 35: 127-191.

Purdy, R.W. 1998. Chondrichthyan fishes from the Paleocene of South Carolina. Transactions of the American Philosophical Society 88(4): 122-146.

Purdy, R.W., V.P. Schneider, S.P. Applegate, J.H. McLellan, R.L. Meyer, and B.H. Slaughter. 2001. The neogene sharks, rays, and bony fishes from Lee Creek Mine, Aurora, North Carolina. Smithsonian Contributions to Paleobiology 90: 71-202.

Quoy, J.R.C., and J.P. Gaimard. 1824. Description des Poissons. Chapter IX. In L. de Freycinet, Voyage autour du monde sur les corvettes de S.M. "Uranie et la Physicienne, pendant les années 1817, 1818, 1819 et 1820, 192-401. Paris.

Rafinesque, C.S. 1810. Caratteri di alcuni nuovi generi e nuove specie di animali e piante della Sicilia, con varie osservazioni sopra $i$ medisimi. Palermo: S. Filippo.

Ramírez-Amaro, S., F. Ordines, A. Esteban, C. García, B. Guijarro, F. Salmerón, B. Terrrasa, and E. Massutí. 2020. The diversity of recent trends for chondrichthyans in the Mediterranean reflects fishing exploitation and a potential evolutionary pressure towards early maturation. Scientific Reports 10(1): 1-18.

Reinecke, T., F. von der Hacht, and K. Gürs. 2008. Die Elasmobranchier des Vierlandiums, unteres Miozän, im nordwestdeutschen Becken aus Bohrungen und glaziofluviatilen Geröllen (,Holsteiner Gestein") der Vierlande-Feinsande (Holstein) und der Kakert-Schichten (Niederrhein). Palaeontos 14: 1-54.

Reinecke, T., S. Louwye, U. Havekost, and H. Moths. 2011. The elasmobranch fauna of the late Burdigalian, Miocene, at WerderUesen, Lower Saxony, Germany, and its relationship with early Miocene faunas on the North Atlantic, Central Paratethys and Mediterranean. Belgium: Palaeo Publishing and Library.

Risso, A. 1810. Ichthyologie de Nice, ou histoire naturelle des poissons du departement des Alpes Maritimes. Paris: F. Schoell.

Rivadeneira, M.M., and S.N. Nielsen. 2017. Diversification dynamics, species sorting, and changes in the functional diversity of marine benthic gastropods during the Pliocene-Quaternary at temperate western South America. PLoS ONE 12: e0187140.

Rögl, F. 1999. Short note: Mediterranean and Paratethys. Facts and hypotheses of an Oligocene to Miocene paleogeography (short overview). Geologica Carpathica 50(4): 339-349.

Rusu, A. 1988. Oligocene events in Transylvania (Romania) and the first separation of Paratethys. Dari de Seama ale Sedintelor Institutul de Geologie si Geofizica 72: 1-73.

Sach, V.J., and E.P.J. Heizmann. 2001. Stratigraphy and mammal faunas of the Brackwassermolasse in the surroundings of Ulm (Southwest Germany). Stuttgarter Beiträge zur Naturkunde, Serie B 310: 1-95.

Sahni, A., and D.K. Mehrotra. 1981. The elasmobranch fauna of coastal Miocene sediments of peninsular India. Biological Memoirs Lucknow 5(2): 83-121.

Sanders, H.L., and R.R. Hessler. 1969. Ecology of the deep-sea benthos. Science 163(3874): 1419-1424.

Sant, K., V.D. Palcu, O. Mandic, and W. Krijgsman. 2017. Changing seas in the Early-Middle Miocene of Central Europe: a Mediterranean approach to Paratethyan stratigraphy. Terra Nova 29(5): 273-281.

Scasso, R.A., and L.N. Castro. 1999. Cenozoic phosphatic deposits in North Patagonia, Argentina: Phosphogenesis, sequence-stratigraphy and paleoceanography. Journal of South American Earth Sciences 12(5): 471-487.

Scholz, H., and R. Bienert. 1992. Bausteine und Fossilien aus der Oberen Meeresmolasse bei Kempten. Berichte des Naturwissenschaftlichen Vereins für Schwaben 96(2): 2-12.

Schultz, O. 1998. Die Knorpel- und Knochenfischfauna (excl. Otolithen) aus dem Karpat des Kronenburger Beckens (Niederösterreich). Beiträge zur Paläontologie 23: 295-323.

Schultz, O. 2013. Pisces. Catalogus Fossilium Austriae 3: 1-576.

Schultz, O., R. Brzobohatý, and O. Kroupa. 2010. Fish teeth from the Middle Miocene of Kienberg at Mikulov, Czech Republic, Vienna Basin. Annalen des Naturhistorischen Museums in Wien (A: Mineralogie und Petrographie, Geologie und Paläontologie, Anthropologie und Prähistorie) 112: 489-505.

Serena, F. 2005. Field identification guide to the sharks and rays of the Mediterranean and Black Sea. FAO Species Identification Guide for Fishery Purposes. Rome: FAO.

Sion, L., A. Bozzano, G. D’Onghia, F. Capezzuto, and M. Panza. 2004. Chondrichthyes species in deep waters of the Mediterranean Sea. Scientia Marina 68(S3): 153-162.

Soaresdee Carvalho, K.D.A.M.R. 2019. The catshark genus Scyliorhinus (Chondrichthyes: Carcharhiniformes: Scyliorhinidae): taxonomy, morphology and distribution. Zootaxa 4601(1): 1-147.

Suarez, M.E., A. Encinas, and D. Ward. 2006. An Early Miocene elasmobranch fauna from the Navidad Formation, Central Chile, South America. Cainozoic Research 4(1/2): 3-18.

Szabó, M., and L. Kocsis. 2016. A new Middle Miocene selachian assemblage (Chondrichthyes, Elasmobranchii) from the Central Paratethys (Nyirád, Hungary): implications for temporal turnover and biogeography. Geologica Carpathica 67(6): 573-594.

Távora, V.D.A., A.A.R.D. Santos, and R. Neto Araújo. 2010. Localidades fossilíferas da Formação Pirabas (Mioceno Inferior). Boletim do Museu Paraense Emílio Goeldi Ciências Naturais 5(2): 207-224.

Thomas, H. 1982. The Lower Miocene fauna of Al-Sarrar (Eastern Province, Saudi Arabia). Journal of Saudi Arabian Archaeology 5: 109-136.

Toledo, P.M. 1989. Sobre novos achados de sirenios (Sirenotherium pirabense Paula Couto, 1976) na Formacao Pirabas (Para, Brasil). Boletim do Museu Paraense Emilio Goeldi Serie Ciencias da Terra 1(1): 5-10.

Underwood, C.J., and G.C. Gunter-. 2012. The shark Carcharhinus sp. from the Middle Eocene of Jamaica and the Eocene record of Carcharhinus. Caribbean Journal of Earth Science 44: 25-30.

Underwood, C.J., and J. Schlögl. 2013. Deep-water chondrichthyans from the early Miocene of the Vienna Basin (Central Paratethys, Slovakia). Acta Palaeontologica Polonica 58(3): 487-510.

Underwood, C.J., S.F. Mitchell, and K.J. Veltcamp. 1999. Shark and ray teeth from the Hauterivian (Lower Cretaceous) of north-east England. Palaeontology 42(2): 287-302.

Uyeno, T., K. Matsuura, and E. Fujii. 1983. Fishes trawled off Suriname and French Guiana. Tokyo: Japan Marine Fishery Resource Research Center.

Vialle, N., S. Adnet, and H. Cappetta. 2011. A new shark and ray fauna from the Middle Miocene of Mazan, Vaucluse (southern France) and its importance in interpreting the paleoenvironment of marine deposits in the southern Rhodanian Basin. Swiss Journal of Palaeontology 130(2): 241.

Viana, S.T., M.R. Carvalho, and U.L. Gomes. 2016. Taxonomy and morphology of species of the genus Squalus Linnaeus, 1758 from the Southwestern Atlantic Ocean (Chondrichthyes: Squaliformes: Squalidae). Zootaxa 4133(1): 1-89.

Vicens, D., and A. Rodríguez-Perea. 2003. Vertebrats fòssils (Pisces i Reptilia) del Burdigalià de cala Sant Vicenç (Pollença, Mallorca). Vertebrate fossils (Pisces and Reptilia) of the Burdigalian 
deposits from Cala Sant Vicenç (Pollença, Mallorca). Bolletí de la Societat d'Història Natural de les Balears 46: 117-130.

Villafaña, J.A. 2015. Estructura biogeografica de condrictios de la costa Pacífica de Sudamérica: Dinámicas desde el Neógeno hasta el presente. Master thesis, Universidad Católica del Norte, Coquimbo, Chile.

Villafaña, J.A., and M.M. Rivadeneira. 2014. Rise and fall in diversity of Neogene marine vertebrates on the temperate Pacific coast of South America. Paleobiology 40: 659-674.

Villafaña, J.A., and M.M. Rivadeneira. 2018. The modulating role of traits on the biogeographic dynamics of chondrichthyans from the Neogene to the present. Paleobiology 44: 251-262.

Villafaña, J.A., S.N. Nielsen, S. Klug, and J. Kriwet. 2019. Early Miocene cartilaginous fishes (Chondrichthyes: Holocephali, Elasmobranchii) from Chile: Diversity and palaeobiogeographic implications. Journal of South American Earth Sciences 96: 102317.

Ward, D.J., and C. Galea Bonavia. 2001. Additions to, and a review of, the Miocene shark and ray fauna of Malta. Central Mediterranean Naturalist 3(3): 131-146.

Welcomme, J.L., P.O. Antoine, F. Duranthon, P. Mein, and L. Ginsburg. 1997. Nouvelles découvertes de Vertébrés miocènes dans le synclinal de Dera Bugti (Balouchistan, Pakistan). Comptes
Rendus de l'Académie des Sciences (Series II A - Earth and Planetary Science) 325(7): 531-536.

White, W.T., D.A. Ebert, G.J. Naylor, H.C. Ho, P. Clerkin, A.N.A. Veríssimo, and C.F. Cotton. 2013. Revision of the genus Centrophorus (Squaliformes: Centrophoridae): Part 1-Redescription of Centrophorus granulosus (Bloch and Schneider), a senior synonym of C. acus and C. niaukang Teng. Zootaxa 3752(1): 35-72.

Wijnker, E., T.J. Bor, F.P. Wesselingh, D.K. Munsterman, H. Brinkhuis, A.W. Burger, H.B. Vonhof, K. Post, K. Hoedemakers, A.C. Janse, and N. Taverne. 2008. Neogene stratigraphy of the Langenboom locality (Noord-Brabant, the Netherlands). Netherlands Journal of Geosciences 87(2): 165-180.

Winkler, T.C. 1876. Deuxieme memoire sur des dents de poissons fossiles du terrain bruxellien. Archives du Musée Teyler 4(1): 16-48.

Yearsley, G.K., P.R. Last, and W.T. White. 2008. A new species of sawshark, Pristiophorus delicatus sp. Nov. (Pristionphoriformes: Pristiophoridae), from Northeastern Australia. In Descriptions of new Australian chondrichthyans, eds. P.R. Last, W.T. White, and J.J. Pogonoski, 378-388. Collingwood: CSIRO.

Zbyszewski, G. 1949. Les vertébrés du Burdigalien supérieur de Lisbonne. Lissabon: Services géologiques du Portugal. 